\title{
Managing invasive plants on Great Plains grasslands: A discussion of current challenges
}

\author{
Authors: John F. Gaskin, Erin Espeland, Casey D. \\ Johnson, Diane L. Larson, Jane M. Mangold, Rachel A. \\ McGee, Chuck Milner, Shishir Paudel, Dean E. Pearson, \\ Lora B. Perkins, Chadley W. Prosser, Justin B. Runyon, \\ Sharlene E. Sing, Zachary A. Sylvain, Amy J. Symstad, \\ Daniel R. Tekiela
}

(C) This manuscript version is made available under the CC-BY-NC-ND 4.0 license

Gaskin, John F., Erin Espeland, Casey D. Johnson, Diane L. Larson, Jane M. Mangold, Rachel A. McGee, Chuck Milner, et al. "Managing Invasive Plants on Great Plains Grasslands: A Discussion of Current Challenges." Rangeland Ecology \& Management (May 2020). doi:0.1016/ j.rama.2020.04.003. 


\title{
Managing invasive plants on Great Plains grasslands: A discussion of current challenges ${ }^{\text {th }}$
}

\author{
John F. Gaskin ${ }^{\mathrm{a}, *}$, Erin Espeland ${ }^{\mathrm{a}}$, Casey D. Johnson ${ }^{\mathrm{b}}$, Diane L. Larson ${ }^{\mathrm{c}}$, Jane M. Mangold ${ }^{\mathrm{d}}$, \\ Rachel A. McGee ${ }^{\mathrm{e}}$, Chuck Milner ${ }^{\mathrm{f}}$, Shishir Paudel ${ }^{\mathrm{g}, \mathrm{n}}$, Dean E. Pearson ${ }^{\mathrm{h}}$, Lora B. Perkins ${ }^{\mathrm{i}}$, \\ Chadley W. Prosser ${ }^{\mathrm{j}}$, Justin B. Runyon ${ }^{\mathrm{k}}$, Sharlene E. Sing ${ }^{\mathrm{k}}$, Zachary A. Sylvain ${ }^{\mathrm{a}}$, Amy J. Symstad ${ }^{1}$, \\ Daniel R. Tekiela ${ }^{\mathrm{m}}$
}

\author{
a USDA ARS, Northern Plains Agricultural Research Laboratory, Sidney, MT 59270, USA \\ ${ }^{\mathrm{b}}$ USFS, Lisbon, ND 58054, USA \\ c U.S. Geological Survey, Northern Prairie Wildlife Research Center, St. Paul, MN 55108, USA \\ ${ }^{\mathrm{d}}$ Department of Land Resources and Environmental Sciences, Montana State University, Bozeman, MT 59717, USA \\ e USFS Medicine Bow/Routt National Forests and Thunder Basin National Grassland, Douglas, WY 82633, USA \\ ${ }^{\mathrm{f}}$ USFS Cibola NF, Black Kettle National Grasslands, Cheyenne, OK 73628, USA \\ ${ }^{g}$ Department of Natural Resources Ecology and Management, Oklahoma State University, OK 74078, USA

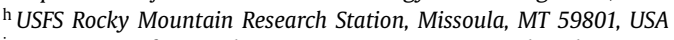 \\ i Department of Natural Resource Management, South Dakota State University Brookings, SD 57007, USA \\ j USFS Dakota Prairie Grasslands, Bismarck, ND 58501, USA \\ ${ }^{\mathrm{k}}$ USDA Forest Service, Rocky Mountain Research Station, Bozeman, MT 59717, USA \\ ${ }^{1}$ U.S. Geological Survey, Northern Prairie Wildlife Research Center, Hot Springs, SD 57747, USA \\ ${ }^{\mathrm{m}}$ Department of Plant Sciences, University of Wyoming, Laramie, WY 82071, USA \\ ${ }^{n}$ Phipps Conservatory and Botanical Gardens, Pittsburgh, PA 15213, USA
}

\section{A R T I C L E I N F O}

\section{Article history:}

Received 29 May 2019

Revised 2 April 2020

Accepted 5 April 2020

Available online $\mathrm{xxx}$

\section{Keywords:}

Grasslands

Great Plains

Plant invasion

Land management

\begin{abstract}
A B S T R A C T
The Great Plains of North America encompass approximately $1,300,000 \mathrm{~km}^{2}$ of land from Texas to Saskatchewan. The integrity of these lands is under continual assault by long-established and newlyarrived invasive plant species, which can threaten native species and diminish land values and ecological goods and services by degrading desired grassland resources. The Great Plains are a mixture of privately and publicly owned lands, which leads to a patchwork of varying management goals and strategies for controlling invasive plants. Continually updated knowledge is required for efficient and effective management of threats posed by changing environments and invasive plants. Here we discuss current challenges, contemporary management strategies, and management tools and their integration, in hopes of presenting a knowledge resource for new and experienced land managers and others involved in making decisions regarding invasive plant management in the Great Plains.
\end{abstract}

(c) 2020 Published by Elsevier Inc. on behalf of The Society for Range Management.

\section{GREAT PLAINS GRASSLAND CHALLENGES}

All invasive plants create management challenges in Great Plains grasslands, but two groups are particularly troublesome either because they are so similar to the dominant vegetation (grasses) or because they transform the very structure of the ecosystem (trees and shrubs). The partially unpredictable nature

\footnotetext{
th This research did not receive any specific grant from funding agencies in the public, commercial, or not-for-profit sectors.

* Corresponding author.

E-mail address: john.gaskin@usda.gov (J.F. Gaskin).
}

of invasive plant dynamics due to their dependence on often accidental dispersal is exacerbated by the Great Plains' highly variable weather becoming even more variable and unpredictable as anthropogenic climate change intensifies. Socio-political context additionally complicates the challenges that grassland managers face.

\section{INVASIVE GRASSES}

The Center for Invasive Species and Ecosystem Health (2018) lists 241 species of exotic grasses and grass-like plants that are on invasive species lists or in noxious weed laws in North America. At least 104 of these are documented in the Great Plains, 
and 22 of these are widespread in the region. Ten species have received substantial attention for their invasiveness in the Great Plains: crested wheatgrass (Agropyron cristatum (L.) Gaertn.); yellow bluestem (Bothriochloa ischaemum (L.) Keng); field brome (Bromus arvensis L.); smooth brome (Bromus inermis Leyss.); cheatgrass (Bromus tectorum L.); Bermudagrass (Cynodon dactylon (L.) Pers.); tall fescue (Schedonorus arundinaceus (Schreb.) Dumort.); reed canarygrass (Phalaris arundinacea L.); European common reed (Phragmites australis (Cav.) Trin. ex Steud.); and Kentucky bluegrass (Poa pratensis L.). We define "substantial attention" as at least five publications appearing in an October 15, 2018 Web of Science search for the species' scientific or common name(s) and "invasive".

Control of invasive grasses is particularly challenging because of their morphological and physiological similarities to the native grasses that comprise a large proportion of the native plant community (Ellis-Felege et al. 2013). Tools that impact invasive grasses often impact desired native grass species. This results in the need for creative application of tools and a necessity to investigate not only the ecological interactions between invasive and native species, but also the interplay among various invasive species. For example, smooth brome and Kentucky bluegrass may respond differently to management (e.g., burning or grazing), so that reduction of one of these species may result in replacement by the other (Hendrickson and Lund 2010).

There are also social perspectives that add to the complexity of Great Plains invasive grass management. Many invasive grasses were intentionally introduced by land managers to increase livestock forage. The livestock forage produced, however, often comes at the expense of less tangible ecosystem services such as wildlife habitat, soil health, and long-term production sustainability. Crested wheatgrass provides a classic example of this complexity. It was introduced in western North America in the late 1800s and early 1900s to increase forage productivity because of its drought resistance and cold and grazing tolerance (Rogler and Lorenz 1983). Crested wheatgrass currently occupies 6-11 million ha of grassland in the Great Plains (Lesica and DeLuca 1996), and it continues to be planted. It can easily spread due to its high seed production and ability to invade native grasslands (Vaness and Wilson 2007). Some managers still see value in crested wheatgrass for soil stabilization and the properties described above. This creates a social challenge, as research has shown that crested wheatgrass negatively impacts several processes in native grasslands both above- and belowground (Vaness and Wilson 2007). A lower root mass than native prairie (Christian and Wilson 1999) leads to a reduced input of organic material and nutrients beneath crested wheatgrass stands (Dormaar et al. 1979, 1995). The species is highly competitive, often resulting in near or complete monocultures. The paucity of plant diversity in crested wheatgrass pastures can lead to lower diversity in vertebrate and invertebrate animals (Lesica and DeLuca 1996).

Other invasive grass species such as cheatgrass and yellow bluestem have also become naturalized placeholders in disturbed landscapes. While not ideal, well-meaning attempts to locally eradicate these plants may lead to an increase in bare ground and an opportunity for other more invasive species, such as jointed goatgrass (Aegilops cylindrical Host), to take hold (Pearson et al. 2016a).

Mitigating the negative impacts of invasive grasses will require consistent and widespread education of public and private land managers about these negative impacts. Presenting in a manner that effectively weighs invasive grass short-term benefits, such as forage or biofuel production, against their long-term impacts is necessary to reduce the purposeful cultivation of invasive grass species and their spread, and to manage invasive grasses at a landscape scale.

\section{WOODY INVASIVES}

Woody plants have encroached in many grassland and savanna ecosystems worldwide in recent years, and they continue to expand (Hodgkinson and Harrington 1985; Grover and Musick 1990; Van Auken 2000). Increasing encroachment by woody species (both native and exotic) exacerbates fragmentation and is difficult to reverse (Engle et al. 2008). Woody encroachment ultimately decreases herbaceous production and diversity, reduces wildlife habitat, and increases bare ground and soil erosion potential (Scholes and Archer 1997). Although woody encroachment occurs globally and includes many species, geographically distant ecosystems suffer similar deleterious effects (Asner et al. 2004). Increases in woody plant encroachment are attributed to fire suppression, livestock overgrazing of herbaceous species, and enhanced seed distribution via intentional plantings, livestock or wildlife (Kramp et al. 1998; Van Auken 2000; Symstad and Leis 2017). Overgrazing by livestock has the dual effect of weakening the competitive ability of grasses against emerging woody plant seedlings and reducing the amount of herbaceous fine fuel that normally supports fires (Archer et al. 1995; Miller and Rose 1999). Woody plant dominance in former grasslands is often considered a "stable state" in that it is irreversible without a major disturbance or strong anthropogenic inputs (i.e., severe prescribed fire and/or mechanical or chemical treatments) to destroy the woody canopies (Archer 1990; Miller et al. 2000). In the Great Plains, grasslands invaded by juniper (Juniperus spp.) species provide a robust example of a woodland stable state (Limb et al. 2014).

Native to North America, junipers, primarily eastern redcedar (J. virginiana L.), have expanded beyond their historical ranges since the late 1800s (Gehring and Bragg 1992) after being planted extensively for windbreaks and habitat for a few wildlife species (West 1988; Ganguli et al. 2008). They have encroached over 10 million ha of grasslands in the southern prairie states of Texas and Oklahoma (Engle 1985; Ansley et al. 1995; Ueckert et al. 2001). Conversion of grasslands through woody encroachment exacerbates landscape fragmentation (Coppedge et al. 2001a), alters hydrological processes (Zou et al. 2014), eliminates habitat for grassland species, including many declining grassland-endemic bird species (Coppedge et al. 2001b; Rosenstock and Van Riper 2001; Horncastle et al. 2005; Engle et al. 2008; Frost and Powell 2011), reduces plant species richness (Ratajczak et al. 2012), and changes carbon cycling and storage (Barger et al. 2011; Wessman et al. 2004). Invasion by these native species also has societal effects, including lost livestock forage, lost or fragmented ranches, increased intensity of wildfire resulting from increased fuel loading (Burkinshaw and Bork 2009), and human health issues exacerbated by allergenic juniper pollen pulses (Van de Water et al. 2003). For example, herbaceous production often declines significantly with as little as $10 \%-20 \%$ of juniper canopy cover (Limb et al. 2010), which in turn reduces stocking rate and carrying capacity of the grasslands.

Although junipers are the primary woody invasive threat to Great Plains grasslands, many deciduous species are also problematic, especially in the eastern portion of the Plains. Species both native to North America and introduced to the continent have expanded in grasslands. For example, native sumac (Rhus glabra L.) and dogwood (Cornus drummondii C.A. Mey.) shrubs invade tallgrass prairie in the central Great Plains (Lett et al. 2004; Hajny et al. 2011), and native aspen (Populus deltoides W. Bartram ex Marshall) encroaches into northern prairies (Grant and Murphy 2005). Non-native Russian olive (Elaeagnus angustifolia L.), Siberian elm (Ulmus pumila L.), and Chinese tallow (Triadica sebifera (L.) Small) are just a few of many troublesome non-native woody encroachers (Siemann et al. 2007; Symstad and Leis 2017). 
The condition of grasslands in the Great Plains reflects past practices. Appropriate grazing practices based on watershed needs and animal behavior must be established. Unless fire is reintroduced into the system, it will be impossible to maintain the correct mix of shrubs and grasses per ecological site descriptions. Coordinating these activities among all owners (federal, state and private) and others with an interest in the land increases everyone's ability to restore ecosystem health.

\section{CLIMATE CHANGE}

Climatic factors affect the distribution of invasive plants both through direct physiological constraints to each species and through indirect effects of climatic influences on competitors, pollinators, pathogens, insect herbivores, grazing pressure, and disturbance regimes. The Great Plains is a diverse region with its ecosystems shaped by distinct climatic gradients (i.e., northsouth gradient in average temperature and east-west gradient in precipitation), inherently high intra- and interannual variation in precipitation (Borchert 1950) and land use changes (i.e., agriculture and energy development). The region also experiences multiple climatic and weather hazards, including extreme droughts, severe winter storms, tornados, floods, soil erosion, and dust storms (Joyce et al. 2001). Although the native ecosystems evolved with this variability and volatility, the resulting variability in services the ecosystems provide to humans causes billions of dollars of economic damage (Shafer et al. 2014).

The Fourth National Climate Assessment (USGCRP 2017) shows that anthropogenically driven climate change is already detectable in the Great Plains and is expected to continue. Specifically, annual average temperature has risen $0.4^{\circ} \mathrm{C}$ in the south and $0.9^{\circ}$ $C$ in the north since the first half of the 20th century, with more of this change occurring in minimum than in maximum temperatures. The Northern Great Plains has experienced one of the largest reductions in extreme cold temperatures in the contiguous United States, but the frequency of intense heat waves in the Great Plains has remained steady. Whereas these temperature changes are unidirectional, well defined, and clearly driven by human influences on climate (Fahey et al. 2017; Knutson et al. 2017), precipitation trends over the last century are less certain. Annual precipitation has generally increased in the Great Plains since the first half of the 20th century, but at different times of year between the north (spring and fall) and the south (summer, fall, and winter), and the frequency and intensity of thunderstorms (the main source of summer precipitation in the Great Plains) have increased.

Temperature changes experienced so far are relatively small compared to projected changes. From the near present to the middle of this century, annual average temperature in the Great Plains is expected to increase $2.0-2.9^{\circ} \mathrm{C}$, with the number of days per year below $0^{\circ} \mathrm{C}$ and above $32^{\circ} \mathrm{C}$ to decrease by 20-30d and increase by $30-40 \mathrm{~d}$, respectively, throughout most of the region. The greater complexity of processes that drive precipitation events and amounts compared to temperature, as well as naturally high interannual variation in precipitation (Borchert 1950), lead to precipitation projections for the Great Plains largely indistinguishable from historical means, with the exception of wetter winters and springs in the northern half of the Plains by the end of this century. However, a warmer atmosphere leads to high confidence in more frequent and more intense heavy precipitation events (frequency increasing by $8-13 \%$ by the middle of this century), less precipitation as snow than as rain, and medium confidence that summer soil moisture will be lower throughout most of the region.

The implications for these changes for the suite of plants that currently and could potentially invade the Great Plains will likely be species-specific and only partially predictable (Bradley et al. 2010). For example, Bradley et al. (2009) used bioclimatic enve- lope modeling to project range shifts for five prominent invasive plants in the western United States, four of which also occur in the Great Plains. They found Tamarix spp., a suite of tree species concentrated in riparian areas, to be largely unconstrained by climatic conditions in their study area, but spotted knapweed (Centaurea stoebe L.) and leafy spurge (Euphorbia esula L.) to be constrained by different aspects and combinations of seasonal or annual precipitation and minimum or maximum temperatures. Based on these constraints, they project expansion of the area at risk for invasion by spotted knapweed, but a small contraction of leafy spurge. A similar evaluation of over 1000 invasive plants in the continental United States, but using just three climate metrics, projects all but the northernmost part of the Great Plains to become less suitable for invasive species by the middle of this century (Allen and Bradley 2016). Bioclimatic envelope models such as these rely on accurate descriptions of species' distributions, information that is not always available for invasive species. They also assume that the current distribution of an invasive species is primarily constrained by climate, which because of dispersal or habitat limitations may not be the case for species newly introduced to a region. Furthermore, this type of model does not necessarily capture more complex and indirect effects of climate on species distributions (Wisz et al. 2013). For example, a long-term field experiment found that drought effects on spotted knapweed were contingent on competitive interactions with the dominant native bluebunch wheatgrass (Pseudoroegneria spicata (Pursh) Á. Löve) (Pearson et al. 2017). Therefore, focusing on accumulating the information necessary to capture the complexities and multiple interacting factors in more mechanistic models may be warranted for species expected to be the most highly consequential in the Great Plains.

Some information about climate effects on individual species does exist. Specifically, shorter hydroperiods, which will accompany rising temperatures, have been shown to favor reed canarygrass in Great Plains wetlands (Galatowitsch et al. 2009), and cheatgrass benefitted from warmer temperatures in an experiment in the northern Great Plains (Blumenthal et al. 2016). On the other hand, drought conditions, which are often projected for the future, highly favored the native bluebunch wheatgrass over the invasive spotted knapweed, and even more so when the knapweed root weevil Cyphocleonus achates Fahraeus was present (Pearson et al. 2017). More experiments like these and long-term monitoring will be necessary to predict and manage invasive species in a changing climate.

The major underlying cause of anthropogenically driven climate change, fossil fuel combustion, also affects plant species and their interactions through increased atmospheric $\mathrm{CO}_{2}$ concentration and nutrient (especially nitrogen) deposition. Invasive species may be better adapted than native species to take advantage of these supplements (Dukes and Mooney 1999). A CO 2 enrichment experiment in a greenhouse showed that five species of invasive plants in the Great Plains followed this pattern (Ziska 2003), and a field experiment in northern mixed-grass prairie suggests that cheatgrass and field brome respond positively to levels of nitrogen enrichment expected from atmospheric deposition (Symstad et al. 2019). A special report of IPCC (Intergovernmental Panel on Climate Change) working group for North America highlighted the facilitative effect of elevated $\mathrm{CO}_{2}$ and regional climate change on the invasion of woody $C_{3}$ species into $C_{4}$ grasslands (Watson et al. 1998). Nitrogen deposition also favors woody invasion into grasslands along the northern edge of the Great Plains in western Canada (Köchy and Wilson 2001). Predicting the effects of elevated $\mathrm{CO}_{2}$ in the atmosphere and nutrient deposition in combination with climate is extremely difficult, as illustrated by a field experiment combining warming with $\mathrm{CO}_{2}$ enrichment in a mixed-grass prairie of the central Great Plains. In this study, diffuse knapweed (Centaurea diffusa Lam.) and Dalmatian toadflax (Linaria dalmatica (L.) Mill.) fitness 
increased under higher $\mathrm{CO}_{2}$ but not with warming (Blumenthal et al. 2013; Reeves et al. 2015), whereas cheatgrass responded positively to warming but not to $\mathrm{CO}_{2}$ enrichment (Blumenthal et al. 2016).

Managers may feel they have little control over climate change, $\mathrm{CO}_{2}$, and nitrogen enrichment and their influences on the invasive species that plague the areas they manage. To read more about managing for climate change across the Great Plains, see Ojima et al. in this Special Issue.

\section{UNIQUE ASPECTS OF NATIONAL GRASSLANDS}

Publicly owned grasslands are typically utilized differently than private grasslands, which influences plant invasion patterns as well as plant management strategies. Moreover, national parks and monuments, federal and state wildlife refuges, and national grasslands differ in their usage and structure. National Grasslands tend to be the most fragmented public lands, though small size of any land unit makes it susceptible to edge and neighbor effects. National Grasslands provide for livestock grazing on top of other public land uses (Olson, 1997) such as off-road travel, hunting, mining, and energy extraction, any of which can affect levels of disturbance and invasibility.

\section{Land Ownership Patterns}

Seventeen National Grasslands (U.S. Department of Agriculture, Forest Service) encompass $14,805 \mathrm{~km}^{2}(1.1 \%)$ of the Great Plains and they range in size from 6 to $4163 \mathrm{~km}^{2}$. The National Grasslands are unique in that they consist primarily of failed homesteads, typically on submarginal lands, that were acquired by U.S. congressional appropriations from willing sellers. This process resulted most commonly in a checkerboard pattern of public and private ownership within National Grassland administrative boundaries and consequently a mixture of land use types (See Augustine et al. in this Special Issue for how Great Plains land ownership patterns affect biodiversity). Fragmentation of grasslands results not only in smaller total area, but also increased edge effects and loss of connectivity. For example, the Black Kettle National Grassland in Oklahoma, containing around 12,000 ha, has approximately $730 \mathrm{~km}$ of boundary or edge. A similar-sized but more contiguous tract of land might have less than $50 \mathrm{~km}$ of boundary or edge. Smaller areas with greater edge-to-area ratios are more susceptible to invasion, and habitat corridors connecting fragments may facilitate movement of undesired (invasive) species (Wilkerson, 2013). It is a challenge to routinely inspect and survey every acre for new infestations on such checkerboard ownership landscapes, making early detection and rapid response difficult. Invasive populations may be contained within the smaller parcels, but if a total landscape management approach is not taken the invasion source may continue to flourish and spread. Multiple neighboring owners may not share the same concerns over invasive populations, and absentee owners may not even be aware that these populations exist. These and other fragmentation issues, such as urban interface, utility corridors and fence and section lines, may also lead to a decrease in natural historic disturbance processes such as fire, which might otherwise enhance desired biological communities.

\section{Multiple Use}

The concept of multiple use, as adopted and attempted by the National Grasslands, has led to conflicts in eradication efforts against invasive species. Unfortunately, some types of use lead to the spread and propagation of invasive populations. The Great Plains contain economically important energy reserves, but exploitation of these reserves entails construction of a vast network of roads to access gas and oil exploration and drilling and wind energy construction sites (Post van der Burg et al. 2017). Such a network increases fragmentation while elevating the potential for invasive species movement, especially ingress via corridors, while facilitating interaction along expanding edges (Porensky and Young 2013). Increased recreational OHV (off-highway vehicle) driving on public lands also increases the potential for invasive seeds to be spread from infested to non-infested areas. Hunters may quite unknowingly spread invasive seed in commercially bagged small grains used as bait (where this practice is legal). Attempts to limit or cease these activities in an effort to stop or decrease spread is often seen as incongruent with the multiuse concept and as impinging on a perceived right. Grazing of domestic livestock, and cultivation of non-native productive grass species (e.g. yellow bluestem) for agricultural and biofuel production may also spread invasives. National Grassland managers note that oil and gas pads, campgrounds, trails, visitor centers, new roads, vehicles, heavy equipment, and wildlife are all primary sources of invasive plant introduction and spread. Because activities involving disturbance or transportation of equipment or animals of any kind potentially add to invasive plant problems, the risk of any short-term use needs to be considered against the possible damage to the long-term integrity of these grasslands.

\section{U.S. Forest Service Administrative Challenges}

The following common administrative challenges faced by National Grasslands invasive plant managers are shared by neighboring land managers and directly or indirectly affect their land management efforts. We openly state them for future discussion and awareness.

- High turnover of National Grassland staff leads to fewer effective long-term coordination efforts with long-term private (e.g., family-owned properties) and public neighboring land managers.

- Personal connections are powerful tools for overcoming conflict and increasing efficacy. There is often not enough worktime available to build these connections with neighboring land managers; thus, coordination efforts suffer.

- The ratio of paperwork to on-the-ground control is relatively high for National Grasslands. More efficient methods for recording and reporting management efforts are needed.

- Land managers have insufficient interaction with invasion researchers. Researchers need to improve technology and information transfer to land managers. National Grassland invasive plant managers should not be dissuaded from attending invasive-plant meetings, especially if they are held locally.

- Managing long-term projects can be difficult when agency goals and priorities change rapidly.

- Invasive plant management is often short-term and reactive, making it difficult to work on ecological and long-term scales.

Many of these challenges, but especially the last, stem from funding and labor shortages. Funds once used to manage forests and grasslands are now often dedicated to wildfire suppression, the costs of which have risen because of climate change, past fire suppression, and the ever-increasing wildland/urban interface. A recent report (USDA Forest Service, 2015) revealed that, "Since 1998, fire staffing within the Forest Service has increased 114 percent, from around 5700 employees in 1998 to over 12,000 employees in 2015. Over the same period, staffing dedicated to managing National Forest System lands has decreased by 39 percent- from approximately 18,000 in 1998 to fewer than 11,000 in 2015". The reduced amount of overall staffing has also led to those responsible for land management spending less time in overall invasive management and more on administrative and overhead duties. The 
Vegetation and Watershed Management program on the National Grasslands experienced a reduction in funding of approximately $24 \%$ from 2001 to 2015. "Reduced funding since 2001 has decreased the rate of restoration that the agency could have achieved across all [National Forest System] landscapes had funding levels been maintained. The reductions have limited the agency's ability to prevent and limit the spread of invasive species..." (USDA Forest Service, 2015). Although cooperative efforts among National Grasslands sometimes increase their ability to manage invasive species, geographic isolation makes this impossible for some units.

\section{INVASION MANAGEMENT STRATEGIES FOR GRASSLANDS}

As with any management challenge, a strategic approach to controlling invasive plants in Great Plains grasslands will be more successful than piecemeal, uncoordinated actions. One mechanistic ecological framework for invasive plant management targeted towards rangelands is supplied by EBIPM (Ecologically Based Invasive Plant Management; Sheley et al. 2010). Regardless of the method used, a strong invasive plant management strategy will include clear goals derived from a set of transparent priorities, and it will weigh expected costs and benefits of actions or lack thereof.

\section{SETTING GOALS}

Because plant invasions advance across grassland ownership and administrative boundaries, successful strategies will often involve multiple landowners and agencies. This presents challenges as it forces the interplay of a diversity of management goals in discussions and planning. The definition of "success" in invasive plant management depends on who is defining it (e.g., a production rancher vs. a conservation organization), where actions are occurring (such as different types of public land), which species are being managed (livestock and/or wildlife palatability are crucial), and other complexities. When all stakeholders are involved in defining "success", resultant goals are unlikely to focus solely on killing a single invasive species but instead will consider plant community structure and function, ecosystem processes, and promoting competitive native species within invaded communities. As an example, grazing of leafy spurge by sheep can suppress the reproductive capability of targeted spurge populations (Johnston and Peak, 1960). Because eradication of the leafy spurge population is not likely to occur, setting it as a goal is unrealistic. Instead, a reasonable goal would be suppression sufficient to mitigate impacts to livestock and wildlife forage with reasonable cost.

One approach to overcoming barriers to defining common goals or a mutual definition of "success" is to develop highly ambitious, long-term goals intended to inspire innovation and to challenge those involved to achieve what currently seems impossible (Sutton, 2000). When doing so, managers must be aware of shifting baseline syndrome (Pauly, 1995) and environmental generational amnesia (Kahn 2002), when human memory of an ecosystem and its associated characteristics fade as exposure to, and memories, of intact ecosystems become more remote in time. Regardless of how ambitious the invasive plant management goals, it is critical that land managers and stakeholders establish clear expectations and agree on their definition of success prior to initiating cooperative invasive plant management efforts. This enables all parties to better prioritize management efforts and apply management tools in a deliberate management strategy.

\section{SETTING PRIORITIES}

Because there are rarely sufficient resources available to fully address the onslaught of plant invaders in Great Plains grasslands, effective management requires strategic prioritization of survey, inventory, treatment and monitoring activities to ensure that actions taken are both fiscally responsible and ecologically effective. Key prioritization considerations include determination of 1) when to address invasions, 2) which invaders are most important to address, and 3) where to address them (Olsen et al., 2015). Developing then evaluating different management scenarios through these three lenses can distinguish the pros and cons of each scenario with regard to a project's definition of success.

\section{When to Address Invasive Plants}

Deciding when to address invasive species may be the easiest part of building a strategy because earlier is always better than later. Addressing invasives before they become established in a new area (i.e., prevention) is often the most cost-effective strategy for managing invasive plant species (Center for Invasive Species and Ecosystem Health, 2018). A proactive approach to prevention may use natural disturbances (fire and grazing) to manage native grasslands, minimizes soil disturbance, and prevents the introduction of invasive species into new areas. Prevention requires actions to educate and raise awareness with internal and external audiences about invasive species threats and respective management solutions. Including preventative measures in standard operating procedures for activities known to transport plant parts (e.g., weed wash stations during fire suppression efforts) is imperative. For example, weed prevention areas (WPAs) that bring together multiple landowners in eastern Montana protect rangelands by interrupting the movement and spread of invasive plants (Goodwin et al. 2012), and the USDA Forest Service has a Guide to Noxious Weed Prevention Practices (USDA 2001). Prevention also applies to previously treated and restored areas. In order to prevent reinvasion after control actions cease, the underlying causes or facilitators of invasion must be removed.

If prevention fails, rapid response to an infestation will save time, money, and ecological integrity (Hobbs and Humphries 1995; Leung et al. 2002; Anderson 2005). Strategies that prioritize targeting small, new infestations consistently outperform strategies that target large established patches (Frid et al. 2013). As the size and extent of areas infested increase, cost of control increases and management goals shift from eradication to containment and control (Figure 1). This principle recently led to the formation of the Northeastern Wyoming Invasive Grass Working Group (https: //www.scweeds.com/newigwg) after two highly impactful invasive annual grasses (medusahead [Taeniatherum caput-medusae (L.) Nevski] and North Africa grass [Ventenata dubia (Leers) Coss.]) were found in Sheridan County, Wyoming. The group launched an extensive education program to teach others in the region how to identify the two species and to help those with already infested lands collaborate to develop region-specific management tools and approaches. Rapid response early in the invasion stage is only possible, however, if sufficient effort is placed into surveying highpriority or high-risk areas for new infestations. The National Park Service's inventory and monitoring programs in the Great Plains therefore include some aspect of early detection in their standard vegetation monitoring protocols (Young et al. 2007; Symstad et al. 2012; Folts-Zettner et al. 2016).

\section{Which Invasive Species to Address}

Determining which species are most important to address requires understanding invasiveness, proximity to the analysis area, current and potential distribution, ecological impacts, and any legal mandates (e.g., noxious weed listings) for each species that occurs within or adjacent to the analysis area (Olsen et al. 2015). 


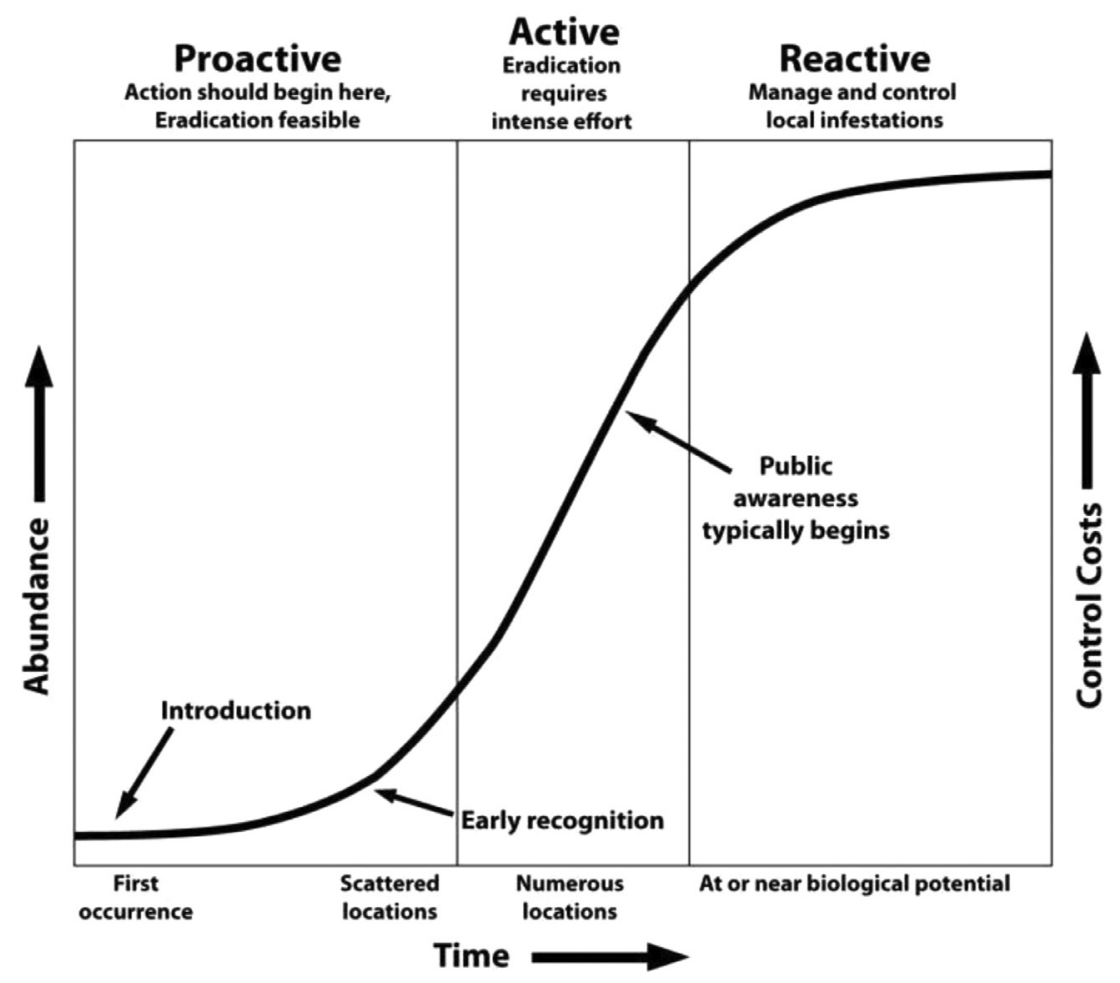

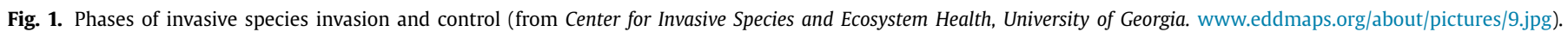

Databases such as the Early Detection \& Distribution Mapping System (https://www.eddmaps.org/distribution/) provide information on species' current distributions, and some research and resulting user-friendly tools exist for predicting the potential distribution of a limited number of species (e.g., Invasive Species Habitat Tool, https://engelstad.shinyapps.io/dashboard_dev/dashboard_ dev.rmd), but there are still substantial data gaps hindering this step in prioritizing species.

Recent advances in quantifying invasive plant impacts are generating new metrics for prioritizing invasive plant management within and among habitats (Thiele et al. 2010; Barney et al. 2013; Pearson et al. 2016b). Methods now exist for quantifying the relationships between individual invaders and native plant abundance within systems containing multiple invaders, allowing for the ranking and prioritization of invaders according to real-time measures of their "apparent impacts" within each habitat (Pearson et al. 2016b). These metrics, including invaded range, invader abundance and per-capita effects of an invader on native species, are termed "apparent impacts" because they are based on correlations between invader abundance and native plant abundance from survey data. In contrast, measuring true impacts requires using costly and time-consuming experimental approaches, which are logistically infeasible to apply to multiple simultaneous invaders. Comparison of the resulting impact rankings for species in Intermountain and Great Plains grasslands with the state noxious weed list reveals three types of invaders. First, the most significant noxious weeds are identified with this method as having the highest impact rankings, thus providing corroboration between noxious weed listing and empirical data (Pearson et al. 2016b). Second, this approach identifies high-impact grasses that may not be included on noxious weed lists because they provide livestock forage and biofuel. This is important because recognizing the negative impacts specific to this category of invasive plants is critical for grassland managers wishing to prioritize, for example, native plant and pollinator diversity over grazing objectives. Third, these empirical surveys can identify "sleepers", early-stage-invaders not yet recog- nized as impacting native systems. This provides a critical advantage in prioritizing new invaders by quantifying their impacts.

As an example, the shrub common buckthorn (Rhamnus cathartica L.) is recognized as a serious pest and noxious weed in the wetter systems of the northeastern United States, but little was known about this invader in the semi-arid west where it is less abundant (Knight et al. 2007). This species was proposed for state noxious weed listing in Montana in January 2016 by the Missoula County Weed Board based on thickets of the plant in local riparian areas associated with horticultural plantings. However, the paucity of information at the time made it unclear whether the species was truly invasive or simply an adventive naturalized species originating from historical plantings. Hence, a survey was initiated during the 2016 field season to assess buckthorn's potential impacts on native plants by targeting populations located in three major river drainages across the state, two of which drain into the Great Plains. Results indicated that this invader's populations were expanding and demonstrating evidence of substantial impacts on native riparian vegetation (Ortega and Pearson 2019). The results were generated in time for the pending noxious weed hearings and the species was listed as a Montana noxious weed in December 2016 (Montana Administrative Register 2019).

Several other prioritization tools and systems exist, many of which are summarized and compared in Olsen et al. (2015), but most of these tools require species-level information that is often unavailable except for well-established species. Consequently, local- or region-specific efforts like those described above would greatly improve species prioritization in Great Plains grasslands.

Where to Address Invasive Species

Prioritizing areas for invasive plant management is as important as prioritizing species and the two must be considered in concert. Prioritization of areas is often where the ecological, social, and feasibility aspects of invasive plant management merge, as different 
stakeholders may weigh ecological and feasibility criteria differently.

Applying a weed impact ranking approach across habitats reveals how invader impacts vary among habitats and how overall invasibility varies by habitat (Pearson et al. 2016b, Pearson and Ortega 2017). For example, invasive plant impact surveys identified $166 \%$ more exotic plant species (48 vs 29 species in bluebunch vs western wheatgrass, respectively), $700 \%$ more noxious weeds (6 vs 1 species), and 550\% more impact species (11 vs 2 species) in western Montana's bluebunch wheatgrass habitat versus western wheatgrass (Pascopyrum smithii (Rydb.) Á. Löve) habitat in the Northern Great Plains of eastern Montana. Although differences in invasion rates could not be entirely ruled out, these differences were attributed largely to greater resistance and resilience of the western wheatgrass system to invasion. Both systems were heavily grazed, suggesting comparable disturbance levels, and most of the problematic western Montana invaders were present in roadside ditches and/or riparian areas near the western wheatgrass habitat, indicating their propagules were present. From a prioritization standpoint, these data suggest a greater need to prioritize invasive plant management in the bluebunch wheatgrass grassland. Moreover, the impact rankings allow for explicit prioritization of the invaders within each habitat, independent of its relative invasibility. For example, crested wheatgrass was the highest-impact invader in the western wheatgrass system but was not identified as a problem in the Intermountain grassland. In contrast, spotted knapweed was the second highest impact invader in the Intermountain grassland but was not found in the western wheatgrass uplands even though this same species demonstrated significant impacts on native plants in adjacent western wheatgrass floodplain habitats (Pearson and Ortega 2017). When this detailed, habitatspecific information is lacking, invasibility of a parcel may be informed by using network analysis methods to assess connectivity among grassland fragments and therefore the likelihood of invasive species spread (Haddad et al. 2014; Perry et al. 2017).

A grassland parcel's position within an existing invasion interacts with both ecological and feasibility criteria important for prioritizing by area. When eradication of the species from the whole area is no longer feasible, small, satellite populations outside the main infestation are good candidates for high priority treatment, after which the perimeter of a large infestation becomes the priority (Hulme 2006). This containment approach is most effective with species that spread slowly, move short distances, and for which effective barriers can be established (Hulme 2006). In the Great Plains, perennial grasses that spread primarily by rhizome, rather than prolific seed-producers, may be the best candidates for containment. A related prioritization criterion is the amount of native (or otherwise desired) plants in or near the parcel, as this will affect whether even a successfully treated target species will reinvade or if the parcel is susceptible to secondary invasion (Pearson et al. 2016a). Parcels that contain a more intact desirable plant community are more likely to resist reinvasion or secondary invasion than those that are dominated by undesirable invasive species. As a result, the likelihood of achieving management goals is higher which may lead to these areas being a higher priority for treatment. For example, native western wheatgrass outcompetes and limits the growth of nonnative sickleweed (Falcaria vulgaris Bernh.), an emerging problem on the Fort Pierre National Grassland. Reducing disturbances, such as heavy grazing, that weaken western wheatgrass may be all that is necessary to control sickleweed when the competitive native species is present (Butler and Wacker 2013).

Prioritization of a parcel should also consider potential impacts of the management treatments on non-target species or resources. Even if an invasive plant species is successfully eradicated, contained or suppressed, a project can be a failure if conservation goals are not achieved due to persistent non-target impacts or undesirable consequences. For example, a control effort may damage desired species through trampling or herbicide spray drift, impact water quality, or contaminate the soil. Such non-target impacts may lead to public opposition to all future control efforts regardless of their safety (Zimmerman et al. 2011). Non-target impacts and unintended consequences can be mitigated by selectively treating particular areas, phasing treatment plans, and completing follow-up management actions (e.g., restoration).

\section{WEIGHING COSTS AND BENEFITS}

Each parcel of land and invasive plant management problem faces multiple feasibility issues. Zimmerman et al. (2011) identify several feasibility criteria to consider, including the number of treatments required to achieve control of each species, the ability to detect and prevent reinvasion of an area, the availability of resources to implement treatments, and, in some cases, the socialpolitical environment. They provide three questions to consider for this last criterion: 1) is social resistance to eradication expected? 2 ) is the invasive species cultivated for horticultural or agricultural uses? and 3) within the invaded area, do all the agencies, organizations and landowners agree to participate? All of these factors must be weighed against each other, the conservation benefits and consequences of acting or not acting, and the cost of each action. A variety of structured decision making tools (e.g., Maguire 2004; Liu et al. 2012; Nielsen and Fei 2015) hold promise for improving the return on investment of managing invasive plants in the Great Plains through more robust management strategies.

\section{TOOLS AND INTEGRATED WEED MANAGEMENT}

The financial cost and ecological benefits of implementing any invasive plant management strategy will depend largely on the exact actions taken. We consider the advantages and disadvantages of the major tools for restoration and integrated invasive plant management in the Great Plains.

\section{HERBICIDES}

Herbicides represent one of the most powerful tools for invasive plant management in grassland systems. They can be applied easily with reasonable precision and often with immediate results (Sheley and Jacobs 1997; Rice and Toney 1998; Ortega and Pearson 2010). In spite of ease of use and immediate results relative to other management tools such as biological control, many grassland invaders like spotted knapweed (Sheley and Jacobs 1997; Rice and Toney 1998; Ortega and Pearson 2010), leafy spurge (Lym and Messersmith 1985; Hein and Miller 1991), Dalmatian toadflax (Jacobs and Sheley 2005), or Canada thistle (Louda and O'Brien 2002) require multiple herbicide applications over time to provide lasting suppression. When integrated with other management tools, herbicides can facilitate even better control of grassland invaders (Lym and Nelson 2002; Sheley et al. 2004; Miller 2016). For instance, in central Oklahoma, herbicide application in conjunction with fire effectively reduces eastern redcedar encroachment into grassland compared to herbicide application alone (Scholtz et al. 2018).

Although the most widely used herbicides in natural areas are directed at invasive forbs, some grass-specific herbicides or strategically timed applications of broadleaf or non-selective herbicides can provide effective control of key invasive annual grasses like cheatgrass or field brome. The development of new herbicides with more specific applications is increasing the precision and efficacy of this tool (DiTomaso and Kyser 2015; Sebastian et al. 2016). For example, indaziflam is a cellulose biosynthesis inhibiting herbicide; 
a new mode of action relative to other herbicides that have been developed for invasive annual grass control (Sebastian et al. 2016, 2017). Review of existing herbicides through the lens of new potential applications can also lead to increased opportunities. As an example, quinclorac, a highly selective auxin herbicide that was initially used in rice to control a broad range of weeds including barnyard grass (Echinochloa crus-galli (L.) P. Beauv.) (Grossmann 1998), is now being used to manage leafy spurge under more challenging circumstances in mesic habitats (Erickson et al. 2006).

Non-target impacts can be reduced by choosing herbicides with a narrower spectrum of activity or less persistence in the environment. Consider possible options for controlling invasive thistles. They can be effectively managed with herbicides applied in the fall when many native forbs have senesced. Thistles can also be managed with herbicides that have multiple active ingredients, some of which exhibit higher selectivity than others; for example, clopyralid has higher selectivity and lower persistence than picloram (Ralphs et al. 1990; Rice et al. 1997; Rice and Toney 1998; WSSA 2014). Studies also show that carefully assessing the reapplication interval can allow sufficient time for less sensitive native species to recover while still suppressing the target invader (Crone et al. 2009).

Spatial precision in the application of the herbicide can reduce side effects by reducing herbicide contact with non-target species. Spot- versus broadcast-spraying invasive plants has been shown to maintain species diversity while still reducing invader abundance (Krueger-Mangold et al. 2002; Pokorny et al. 2010). Where an invader is widely and evenly distributed across a vast landscape, which is common in grasslands, spot spraying is inappropriate. Accordingly, broadcast (ground or aerial) applications may be a good strategy for initial control over large areas, but more targeted applications are appropriate thereafter.

\section{BIOLOGICAL CONTROL}

Biological control of weeds (the importation and release of exotic, co-evolved natural enemies to control non-native plants), has been practiced in the USA since the 1930s (Briese 1997). Biological control has had success in the grasslands of North America against leafy spurge, Dalmatian toadflax, diffuse knapweed and bull thistle (Cirsium vulgare (Savi) Ten.) (Seastedt et al. 2003; Winston et al. 2017), although treatment outcomes are often highly variable across habitats, regions and years (McFadyen 2000). Biological control can also be controversial. The thistle seedhead weevil (Rhinocyllus conicus Frölich) was introduced in 1969 and effectively controlled many exotic thistles (Winston et al. 2017). Host specificity tests suggested that native North American Cirsium species would be similarly attacked, but at that time, conservation of native thistles was not as highly prioritized (Gassmann and Louda 2001). Some biological control agents are simply ineffective. For Canada thistle, the widely established thistlestem weevil (Hadroplontus litura Fabricius) and stem gall fly (Urophora cardui Linnaeus) are still actively distributed but have very limited effect on populations (Price 2014). Best practices have evolved over time to improve biological control, mostly through better hostspecificity and efficacy testing, increased post-release monitoring, and a focus on habitat community health (Balciunas and Coombs 2004).

Success of biological control can often be improved through integration with other control methods (Lake and Minteer 2018). Grazing early in the growing season when weeds are more palatable or nutritious can provide high quality forage for livestock while creating optimal conditions for biocontrol agents with a preference for less dense stands of vegetation, such as the leafy spurge flea beetle (Aphthona spp.) (Bourchier et al. 2006). Although grazing and other non-selective methods of biomass removal can negatively impact biological control agents, species such as bison selectively feed on grasses and thus avoid harming stem dwelling agents such as the toadflax stem miners (Mecinus janthinus Germar and M. janthiniformis Tosevski \& Caldara; Sing et al. 2016).

Current controversies in biological control of weeds that affect Great Plains grasslands exist. They include the termination of USDA APHIS permits to move tamarisk leaf beetles (Diorhabda spp.) across state lines. This was caused by a perception that defoliation of Tamarix would impact critical habitat of the endangered southwestern willow flycatcher (Empidonax traillii extimus Audubon) in some western riparian ecosystems (Dudley and Bean 2012). Though approved for release in Canada, permits were also not issued for the houndstongue (Cynoglossum officinale L.) root weevil (Mogulones crucifer Herbst) in the USA due to potential nontarget attack. In Canada, damage to a native Boraginaceae species by the root weevil has been limited to temporary spillover (Catton et al. 2015). This weevil has migrated to the northwestern USA, so there is ongoing research to predict its effect on protected native species under field conditions. Because a permit to release M. crucifer in the USA has not been issued, it is considered a plant pest and therefore cannot be legally transported across state lines, and redistribution in states where it has already become established is strongly discouraged by federal regulatory agencies (Montana Invasive Species Council 2019).

Biological control research for some important grassland invaders is nearing the end of the research phase, and petitions for permits to release candidate agents will soon be submitted for a mite (Aceria angustifoliae Denizhan, Monfreda, de Lillo \& Cobanoglu) and a moth (Anarsia eleagnella Kuznetsov) for control of seed production in Russian olive (Sing et al. 2016), and a highly host-specific seed feeder for houndstongue (Mogulones borraginis Fabricius) (Park et al. 2018). A mite (Aceria drabae Nalepa) for hoary cress (Lepidium draba L.) (De Lillo et al. 2017) and a stem-galling weevil (Rhinusa pilosa Gyllenhal) for yellow toadflax (Linaria vulgaris Mill.) (Gassmann et al. 2014) were approved for release in 2018 and deployed in 2019. The Colorado Department of Agriculture (2019) is currently field-testing the efficacy of the host-specific rust Puccinia punctiformis (Strauss) Röhl for control of Canada thistle. This introduced exotic rust is widespread in the USA already, but typically in insufficient abundance to control the weed. Researchers are trying to enhance results by manually moving ground-up spore-laden leaves and applying these on moistened Canada thistle rosettes in the fall.

Important challenges remain in the science of biological control related to understanding the factors affecting success or failure and in predicting agent efficacy (Carson et al. 2008; Sheppard et al. 2005). Genetic analysis of plant populations can be very useful for post-release assessments, to better understand why biocontrol succeeds or fails in specific locations. Biological control of Dalmatian and yellow toadflax, for example, has had to contend with plant hybridization (Ward et al. 2009), which reduces the efficacy of highly host-specific agents, and led to the unintentional introduction of a closely related cryptic agent (Toševski et al. 2013). Plant chemistry is also potentially very important in biological control, and it could be used to better predict which potential agents are most likely to be effective (Wheeler and Schaffner 2013; Runyon and Birdsall 2016). Chemical attractants can also be used to improve upon biocontrol efficacy: establishment and impact of releases of the tamarisk leaf beetle Diorhabda carinulata Desbrochers increased in areas treated with baits containing the agent's aggregation pheromone (Gaffke et al. 2018).

More research is needed to improve the biological control efficacy for leafy spurge. The current agents are effective in many habitats, but control in riparian areas and sandy soils is less effective (Richardson et al. 2008). Grassland managers also need more biological control options for invasive grasses. Grasses are 
not normally targets for biological control due to their close relation to agricultural grains and other native grasses, and fewer insects have co-evolved with these species compared to many forbs. Researchers are just beginning to study the use of exotic mites and rusts as grass agents for species such as cheatgrass, guineagrass (Megathyrsus maximus (Jacq.) B.K. Simon \& S.W.L. Jacobs) and medusahead (Kennedy 2018; Sutton et al. 2019).

\section{PHYSICAL TREATMENTS}

Physical treatments such as hand pulling, cutting, mowing/slashing, mulching, and tilling/hoeing, are among the oldest methods of weed control (Vitelli 2000). Physical methods have had variable success in controlling grassland weeds: they are often labor-intensive, frequently require retreatment, and may not be suitable for topographically challenging sites (Vitelli and Pitt 2006; Mattise and Scholten 1994). Use of mechanical controls can increase weed dominance of plants that readily regenerate from severed root fragments (DiTomaso and Keyser 2007). If a mechanical method is employed, it is imperative that all equipment used be thoroughly cleaned following use to prevent the spread of seeds or propagating root or stem fragments. Physical treatments may also increase soil nitrogen levels and alter soil microclimate, which could be beneficial to biocontrol agents (Hatcher and Melander 2003). Effective control of woody invasives in grassland frequently relies on a mechanically based physical treatment (chaining, bulldozing, roller chopping or shredding/masticating) coupled with herbicide and/or burning (Dodd and Holtz 1972; DiTomaso 2000; Vitelli and Pitt 2006; Davies et al. 2014).

\section{FIRE}

Fire is one of three major agents shaping the evolution and maintenance of Great Plains grasslands (for grazing and climate effects see Twidwell et al. in this Special Issue). Suppression of fire is one factor influencing invasion by juniper and other woody species throughout the Great Plains (Briggs et al. 2005; Fuhlendorf et al. 2008), as well as cool-season grasses in the north (Grant et al. 2009; Vermeire et al. 2011). Because fire is a relatively nonselective tool for controlling invasive species, proper timing of application may be important: early (cool-season) fires are often used to target cool-season invasives in warm-season-dominated tallgrass prairies (Wilson and Stubbendieck 1997; Brudvig et al. 2007). Growing-season fire targets warm-season yellow bluestem in the southern Great Plains (Simmons et al. 2007; Havill et al. 2015) and cool-season annual grasses in Montana (Vermeire et al. 2011), and it may be timed to enhance herbicide effectiveness (Robertson et al. 2013). Native species are largely adapted to growing-season fire and thus are not adversely affected. Consequently, growingseason wildfire in Great Plains grasslands should be not viewed as a source of invasion (Porensky and Blumenthal 2016). Repeated fire applications are likely necessary and possibly should be more frequent and more intense than pre-suppression fire regimes, especially when the target invader is a woody species (Ratajczak et al. 2014; Twidwell et al. 2013).

\section{GRAZING}

Targeted, prescribed grazing has been increasingly used as an invasive species management tool. Along with fire, grazing is the oldest management tools for vegetation (Launchbaugh and Walker 2006). Adoption of grazing animals for control or eradication of invasive plant species helps to reduce herbicide use, improve soil quality, and increase native plant diversity (Popay and Field 1996). Properly managed grazing animals can also provide an economi- cal and environmentally friendly method of suppressing brush encroachment (Campbell and Taylor 2006).

Most grazing strategies for weed control share the general approach of grazing the invasive species during its period of active growth in order to provide maximum control as well as the benefits of forage utilization (Frost and Launchbaugh 2003; Popay and Field 1996; Pringle et al. 2014). In most cases, grazing alone will not be effective at eradicating most weed and shrub species from a grassland. Grazing can, however, be an effective strategy for suppressing a target species by reducing its vigor and/or its ability to flower or spread vegetatively. In extensive infestations where more effective long-term strategies such as selective herbicide application or biocontrol releases aren't feasible, selective grazing can still be used successfully to enhance desirable species in some areas and suppress weed production in other areas (Launchbaugh and Walker 2006).

Timing of grazing is critical as livestock can also spread invasive plant propagules and can damage desirable plant species during critical growth phases (Campbell and Taylor 2006; Launchbaugh and Walker 2006). More research is needed to determine optimal timing for reducing invasive species, and to develop more effective methods to encourage livestock utilization of target species.

\section{RESTORATION}

Restoration is part of an integrated invasive plant management strategy in that it bolsters populations of native species that may have been reduced by weeds, returns species that may have disappeared from the site, and supports biotic resistance of the community to prevent additional invasions. Here we discuss seeding and seed sources, forb establishment, and soil conditions as they apply to weed control in grasslands.

\section{Seeding and Seed Sources}

Restoration of upland areas in the Great Plains is usually conducted by seeding. Failures are often attributed to maladaptation of the planted materials to the restoration site (Kettenring et al. 2014; Altricher et al. 2017), competition from weeds, and inappropriate seedbed preparation or seed application. Scientists have identified functional trait characteristics of invasive plants that can then be used as targets for trait selection of native species for improved establishment (Jones and Monaco 2007; Rowe and Leger 2012). Important factors contributing to failed seeding efforts include both abiotic constraints linked to precipitation and biotic constraints such as rodent seed predation (Howe et al. 2002; Baker et al. 2003; James et al. 2011). New research is showing that seed coatings can help to overcome these barriers and even reduce seeding costs in the process (Madsen et al. 2016; Pearson et al. 2019). Also, using native annual forbs as a cover crop has been shown to improve perennial grass restoration in North Dakota (Espeland and Richardson 2015). Conversely, in salt-affected soils, non-native cover crops improved site recovery only slightly, with little to no effect on native plant growth (Espeland and Perkins 2013; Espeland et al. 2017).

Seed sources widely available for restoration of the mixed grass prairies are generally "improved" varieties and cultivars of native grass and forb species (e.g., Chivers et al. 2016). It is often unknown if the seeds from these sources were selected and bred to retain important ecosystem functions such as providing pollinator habitat, invasion resistance, nutrient cycling, and carbon sequestration, or if they might also express some maladaptation to a specific restoration environment (Espeland et al. 2017).

As concern rises over declining pollinators and imperiled Monarch butterflies (Danaus plexippus Linnaeus), grassland managers are often advised to increase the number and diversity of 
flowering plants to provide season-long forage for these insects. This advice presents several challenges, such as obtaining sufficient seed at a reasonable cost that can be verified as weed-free. As managers in Minnesota discovered when noxious Palmer amaranth (Amaranthus palmeri S. Watson) was inadvertently included in a mix used for conservation plantings (AgWeb 2018), seed marketed as "pollinator mix" may not receive the same level of contaminant testing required of agricultural seed. One commonly used method of seed sourcing is to combine-harvest a nearby high-quality remnant or reconstructed grassland. While usually cost-effective, there are pros and cons to this method. Benefits include the likelihood that seeds collected are from locally adapted species and that any weeds in the collection will not be new to the region. On the other hand, a single combine-harvest will only collect seeds that are ripe at that time, resulting in a narrow phenological range in the restored grassland unless multiple harvests are pooled or supplemented with hand-collected seeds.

\section{Forb Establishment}

Another challenge to increasing forb diversity is the difficulty in providing conditions suitable for establishment of a broad range of forbs. As diversity of the seed mix increases, the proportion of species that establish often declines (Larson et al. 2018). Moreover, increasing forb diversity for pollinators may conflict with other management goals. When the economic use of grassland is livestock production, adding plants such as milkweed for Monarch butterflies can be seen as reducing forage available to cattle. Grazing by cattle may also influence native bee behavior, with some bee taxa favored by grazing and others not (Kimoto et al. 2012). This leaves open the possibility of using grazing by domestic ungulates as a restoration tool to influence native bee ecosystem services.

\section{Soil Conditions}

Soil conditions play an important role in the success of restoration following invasive species management. A recent area of research shows that invasive plants can affect these conditions through plant-soil feedbacks (PSFs). Invasive plants commonly alter soil nutrient pools and cycling rates (especially nitrogen) and other aspects of soil chemistry such as pH (Ehrenfeld 2003; Hamman and Hawkes 2013; Gibbons et al. 2017). These shifts appear to be consistent among specific invasive plants or functional groups of invaders (Gibbons et al. 2017). Functional group-specific shifts in soils also appear to affect changes to microbial communities (Gibbons et al. 2017), which can have their structure and composition altered by invasive plants (e.g., Callaway et al. 2004; Hawkes et al. 2006; Mummey and Rillig 2006; van der Putten et al. 2007; Hamman and Hawkes 2013). Some grassland invasive plants also exude allelochemicals that are toxic to other plants or to components of the soil microbial community (e.g., spotted and diffuse knapweeds)(Callaway et al. 2004; Vivanco et al. 2004). Chemical and biological alterations to the soil, such as reduced diversity and abundance of arbuscular mycorrhizal fungi, can have direct impacts on native plants' performances, which in turn reduces the diversity and productivity of native plant communities (Mummey and Rillig 2006). For instance, in the southern Great Plains, invasive Caucasian bluestem (Bothriochloa bladhii (Retz.) S.T. Blake) reduces productivity of warm-season native prairie grasses by reducing root colonization by arbuscular mycorrhizal fungi (Wilson et al. 2012).

Plant-soil feedbacks (PSFs) also include interactions with symbionts and pathogens already present in the soil system. Lack of negative PSFs (such as those caused by pathogens) present in their native range may be one reason for the success of invasive plants in their new habitats, such as is the case for spotted knapweed (Callaway et al. 2004). This is supported by evidence suggesting that invasive plants tend to suffer the fewest negative impacts of PSFs in a given plant community. This is especially relevant in grasslands, which tend to have an abundance of negative PSFs that control plant community dynamics (Kulmatiski et al. 2008). Additionally, the effectiveness of weedy species at colonizing disturbed habitats may be related to the fact that many weedy species are early-successional plants, which as a whole appear to benefit most from increasingly negative PSFs acting on plant communities (Kulmatiski et al. 2008). It is worth noting that invasive plants may not be able to successfully create PSFs (which can either benefit the invasive species or negatively impact competitor species) in all soil types: for example, yellow starthistle (Centaurea solstitialis L.) and Kentucky bluegrass do not appear to consistently create or benefit from PSFs. Those invasive plants that do consistently create PSFs, however, appear to consistently benefit from them (Perkins et al. 2016).

Grassland soil conditions can also be disrupted as a consequence of land use, and these conditions may not be addressable using traditional restoration practices. This can lead to habitat conditions favoring invasives over native plants, especially later-successional natives. For example, energy development and restoration of impacted sites in the Bakken oilfield region of western North Dakota have resulted in soils with reduced soil organic matter (SOM), depauperate microbial communities (Viall et al. 2014), and elevated salinity (Sylvain et al. 2019). These disturbed soil conditions then lead to greater amounts of bare ground and plant communities dominated by ruderal weeds and invasive grasses (Simmers and Galatowitsch 2010; Sylvain et al. 2019).

It is likely that management of plant invasions and subsequent restoration efforts will only succeed when soil conditions are addressed in addition to efforts focused on reintroducing native plant species. One potential means to do this is "strategic restoration", using native plants that are tolerant to soil legacies as nurse plants to help condition the soil in preparation for planting desirable native plants that are less tolerant (Jordan et al. 2008; Vink et al. 2015). Soil conditions may also be addressed more directly by influencing soil chemical and physical factors, such as increasing soil organic matter (Viall et al. 2014) or by inoculating soils with microbial communities (Johnson 1998). The latter has shown promise in some grassland circumstances (Rowe et al. 2007; Perkins and Bennett 2018; Rowe et al. 2009; Middleton and Bever 2012; Emam 2016), although responsiveness varies among species. Including arbuscular mycorrhizal fungi during site preparation and seeding has also shown promise in promoting the recovery of desirable grassland plant species (Koziol and Bever 2017), but these methods are still in development. For highly disturbed sites, it may be better to remove the topsoil and incorporate whole-soil inocula from donor sites directly into the mineral soil (transplanting entire communities of bacteria, fungi and soil animals) in order to promote restoration of target plant species present in the donor environment (Carbajo et al. 2011; Wubs et al. 2016). Incorporating activated carbon into soils is another potential treatment, as these compounds strongly adsorb allelochemicals released by invasive plants and can benefit native grasses (Kulmatiski and Beard 2006; Kulmatiski 2011 and references therein).

\section{INTEGRATED WEED MANAGEMENT STRATEGIES}

Defaulting to a single management strategy can lead to ineffective long-term control of invasive weeds and precipitate a decline in long-term efficacy. The best example of the failure of a single strategy is the increasing incidence of herbicide resistance occurring in most agricultural systems. Fortunately, natural grassland systems do not yet have major issues with herbicide resis- 
tance (but see Mangin and Hall 2016). However, there are many examples in grasslands systems where management strategies relying on a single tool are ineffective at long-term control, such as a recent review of Canada thistle management (Davis et al. 2018).

Integrated weed management utilizes multiple management strategies to more effectively respond to both emerging and established invasive weed issues (Masters and Sheley 2001) and ideally considers management of the whole environment to produce a healthier system. Synergies occur when the integration of techniques lead to better control than the sum of techniques alone (Woodyard et al. 2009). For example, various herbicides and biocontrol agents have been relatively ineffective at controlling leafy spurge when used alone, but integration of these tools resulted in better long-term control than either method alone (Lym 1998). This synergy may be time- and order-dependent. For example, perennial pepperweed (Lepidium latifolium L.) is best controlled when mowing occurrs before the herbicide application (Renz and DiTomaso 2006). Integrated weed management must be planned to avoid antagonisms in which the application of multiple techniques results in similar or poorer control than applying a single technique. For example, both prescribed burning and clopyralid have been shown to control yellow starthistle in the short-term, but the combination of clopyralid the first year followed by a prescribed burn actually lead to an increase in germination and thus ineffective control (DiTomaso et al. 2006).

The use of integrated weed management is far less prevalent in natural than agronomic systems. This is likely due to the larger scale at which management must happen, the heterogeneity of many grassland systems, and the diversity of vegetation that must be managed. However, there are examples of successful implementation in natural grasslands (e.g., Derr 2008; Enloe et al. 2005, Lym and Nelson 2002; Miller 2016; Sheley et al. 2004). For instance, the combination of mechanical (mowing and tilling), restoration (seeding competitive species) and chemical (herbicides) techniques provided better control of wild chervil (Anthriscus sylvestris (L.) Hoffm.) than chemical control alone (Miller 2016). Also, grazing can be integrated with herbicides, fire, or traditional biocontrol methods to improve the efficacy and longevity of weed control treatments. Lym et al. (1997) studied the efficacy of grazing and herbicide treatments of leafy spurge on the Sheyenne National Grassland and the Gilbert C. Grafton South State Military Reservation in North Dakota. They found that herbicides in combination with grazing by goats provided better leafy spurge control than herbicides or grazing alone.

Importantly, proper integrated weed management is not a static strategy and is highly site-, environment-, and plant communityspecific. Thus, adaptive management is likely required to respond to annual variation and other uncertainties associated with weed management (Stankey et al. 2005). Adaptive management is the iterative process of modifying management strategies based on system conditions and previous success (Leffler and Sheley 2012). Monitoring must be performed to ascertain management success and is a critical element of most successful long-term integrated weed management.

One example of a successful implementation of structured adaptive management is the Native Prairie Adaptive Management Project (NPAM). Grasslands in the northern Great Plains, whether remnant native prairie or reconstructed prairie, have been heavily invaded by perennial, cool-season, exotic grasses, especially smooth brome and Kentucky bluegrass (DeKeyser et al. 2013). Both are known to invade after control of other invasives, such as leafy spurge (Larson and Larson 2010), but they also invade undisturbed grasslands (Grant et al. 2009; DeKeyser et al. 2015). As the extent of the problem of invasion by cool-season grasses became clear (Grant et al. 2009), biologists and grassland managers from across the region joined forces with a team of decision analysis experts to develop NPAM, a rigorous adaptive management approach focusing on prescribed fire and grazing. The project represents one of the few encouraging outcomes with respect to invasive cool-season grasses in the northern Great Plains (Moore et al. 2013; Kobiela et al. 2017; Moore et al. 2020). Key to the success of this approach was broad buy-in by grassland managers, a clear set of management alternatives and triggers for their use, annual updates, and centralized data analysis to provide timely feedback.

\section{CONCLUSION}

The Great Plains of North America is unique in terms of history, use, and management needs. Current challenges surrounding plant invasions in this region have been discussed here. Improved management and sustainable success in controlling invasive plants lies in changes to our knowledge base, improvement of tools and their integration, more effective administration and support for invasion control, as well as better communication and cooperation between public grassland managers, private landowners, and the public that uses many of these lands. We encourage grassland managers, owners, users and researchers to build on the knowledge presented in this special issue: Great Plains Grasslands Synthesis - Special Issue.

\section{Declarations of Competing Interest}

None.

\section{Acknowledgements}

Any use of trade, firm, or product names is for descriptive purposes only and does not imply endorsement by the U.S. Government. We thank John Hendrickson and two anonymous reviewers for their suggestions on how to improve an earlier version of this manuscript.

\section{References}

AgWeb. 2018. https://www.agweb.com/article/more-palmer-amaranth-hitchhikingon-crp-seed [accessed 11/12/2019]

Allen, J.M., Bradley, B.A., 2016. Out of the weeds? Reduced plant invasion risk with climate change in the continental United States. Biol. Conserv. 203, 306-312.

Altrichter, E.A., Thompson, J.R., Mabry, C.M., 2017. Stakeholders' perceptions of native plants and local ecotypes in ecological restoration. Ecol. Restor. 35, 218-227.

Anderson, L.W., 2005. California's reaction to Caulerpa taxifolia: a model for invasive species rapid response. Biol. Invas. 7, 1003-1016.

Ansley, R., Pinchak, W., Ueckert, D., 1995. Changes in redberry juniper distribution in northwest Texas (1948 to 1982). Rangelands 17, 49-53.

Archer, S., 1990. Development and stability of grass/woody mosaics in a subtropical savanna parkland, Texas, USA. J. Biogeogr. 17, 453-462.

Archer, S., Schimel, D.S., Holland, E.A., 1995. Mechanisms of shrubland expansion: land use, climate or $\mathrm{CO}_{2}$. Clim. Change 29, 91-99.

Asner, G.P., Elmore, A.J., Olander, L.P., Martin, R.E., Harris, A.T., 2004. Grazing systems, ecosystem responses, and global change. Annu. Rev. Environ. Resour. 29, 261-299.

Bakker, J.D., Wilson, S.D., Christian, J.M., Li, X.D., Ambrose, L.G., Waddington, J., 2003. Contingency of grassland restoration on year, site, and competition from introduced grasses. Ecol. Appl. 13, 137-153.

Balciunas, J., Coombs, E., 2004. International code of best practices for classical biological control of weeds. Biological Control of Invasive Plants in the United States, 130-136. Oregon State University Press, Corvallis.

Barger, N.N., Archer, S.R., Campbell, J.L., y. Huang, C., Morton, J.A., Knapp, A.K., 2011 Woody plant proliferation in North American drylands: a synthesis of impacts on ecosystem carbon balance. J. Geophys. Res. Biogeosci. 116, 1-17.

Barney, J.N., Tekiela, D.R., Dollete, E.S., Tomasek, B.J., 2013. What is the "real" impact of invasive plant species. Front. Ecol. Environ. 11, 322-329.

Blumenthal, D.M., Kray, J.A., Ortmans, W., Ziska, L.H., Pendall, E., 2016. Cheatgrass is favored by warming but not $\mathrm{CO} 2$ enrichment in a semi-arid grassland. Glob. Change Biol. 22, 3026-3038.

Blumenthal, D.M., Resco, V., Morgan, J.A., Williams, D.G., LeCain, D.R., Hardy, E.M., Pendall, E., Bladyka, E., 2013. Invasive forb benefits from water savings by native plants and carbon fertilization under elevated $\mathrm{CO} 2$ and warming. New Phytol. 200, 1156-1165.

Borchert, J.R., 1950. The climate of the central North American grassland. Ann. Assoc. Am. Geogr. 40, 1-39. 
Bourchier, R., R. Hansen, R. Lym, A. Norton, D. Olson, C.B. Randall, M. Schwarzlander, and L. Skinner. 2006. Biology and biological control of leafy spurge. US Department of Agriculture Forest Health Technology Enterprise Team.

Bradley, B.A., Blumenthal, D.M., Wilcove, D.S., Ziska, L.H., 2010. Predicting plant invasions in an era of global change. Trends Ecol. Evolut. 25, 310-318.

Bradley, B.A., Oppenheimer, M., Wilcove, D.S., 2009. Climate change and plant invasions: restoration opportunities ahead. Glob. Change Biol. 15, 1511-1521.

Briese, D., 1997. Biological control of St. John's wort: past, present and future. Plant Protect. Q. 12, 73-80.

Briggs, J.M., Knapp, A.K., Blair, J.M., Heisler, J.L., Hoch, G.A., Lett, M.S., McCarron, J.K., 2005. An ecosystem in transition: causes and consequences of the conversion of mesic grassland to shrubland. AIBS Bull. 55, 243-254.

Brudvig, L.A., Mabry, C.M., Miller, J.R., Walker, T.A., 2007. Evaluation of central North American prairie management based on species diversity, life form, and individual species metrics. Conserv. Biol. 21, 864-874.

Burkinshaw, A.M., Bork, E.W., 2009. Shrub encroachment impacts the potential for multiple use conflicts on public land. Environ. Manag. 44, 493-504.

Butler, J.L, Wacker, S.D., 2013. Sickleweed on the Fort Pierre National Grassland: an emerging threat. Prairie Nat. 45, 28-38.

Callaway, R.M., Thelen, G.C., Rodriguez, A., Holben, W.E., 2004. Soil biota and exotic plant invasion. Nature 427, 731-733.

Campbell, E., Taylor, C., 2006. Targeted grazing to manage weedy brush and trees. In: Launchbaugh, K. (Ed.), Targeted Grazing: A Natural Approach to Vegetation Management and Landscape Enhancement. American Sheep Industry Association, Cottrell Printing: Centennial: Cottrell Printing, Centennial, CO. USA, pp. $77-88$.

Carbajo, V., den Braber, B., van der Putten, W.H., de Deyn, G.B., 2011. Enhancement of late successional plants on ex-arable land by soil inoculations. PLoS ONE 6.

Carson, W.P., Hovick, S.M., Baumert, A.J., Bunker, D.E., Pendergast, T.H., 2008. Evaluating the post-release efficacy of invasive plant biocontrol by insects: a comprehensive approach. Arthropod-Plant Interact. 2, 77-86.

Catton, H.A., Lalonde, R.G., De Clerck-Floate, R.A., 2015. Nontarget herbivory by a weed biocontrol insect is limited to spillover, reducing the chance of population-level impacts. Ecol. Appl. 25, 517-530.

Center for Invasive Species and Ecosystem Health. 2018. https://www.invasive.org/ species.cfm [accessed 24 October 2019]

Chivers, I.H., Jones, T.A., Broadhurst, L.M., Mott, I.W., Larson, S.R., 2016. The merits of artificial selection for the development of restoration-ready plant materials of native perennial grasses. Restor. Ecol. 24, 174-183.

Christian, J.M., Wilson, S.D., 1999. Long-term ecosystem impacts of an introduced grass in the northern Great Plains. Ecology 80, 2397-2407.

Colorado Department of Agriculture. 2019. https://www.colorado.gov/pacific/ agconservation/canada-thistle-biocontrol [accessed 28 November 2019]

Coppedge, B.R., Engle, D.M., Fuhlendorf, S.D., Masters, R.E., Gregory, M.S., 2001a. Landscape cover type and pattern dynamics in fragmented southern Great Plains grasslands, USA. Landscape Ecol. 16, 677-690.

Coppedge, B.R., Engle, D.M., Masters, R.E., Gregory, M.S., 2001b. Avian response to landscape change in fragmented southern Great Plains grasslands. Ecol. Appl. $11,47-59$.

Crone, E.E., Marler, M., Pearson, D.E., 2009. Non-target effects of broadleaf herbicide on a native perennial forb: a demographic framework for assessing and minimizing impacts. J. Appl. Ecol. 46, 673-682.

Davies, K.W., Bates, J.D., Madsen, M.D., Nafus, A.M., 2014. Restoration of mountain big sagebrush steppe following prescribed burning to control western juniper. Environ. Manag. 53, 1015-1022.

Davis, S., Mangold, J., Menalled, F., Orloff, N., Miller, Z., Lehnhoff, E., 2018. A meta-analysis of Canada thistle (Cirsium arvense) management. Weed Sci. 66, 548-557.

DeKeyser, E.S., Dennhardt, L.A., Hendrickson, J., 2015. Kentucky bluegrass (Poa pratensis) invasion in the northern Great Plains: a story of rapid dominance in an endangered ecosystem. Invas. Plant Sci. Manag. 8, 255-261.

DeKeyser, E.S., Meehan, M., Clambey, G., Krabbenhoft, K., 2013. Cool season invasive grasses in northern Great Plains natural areas. Nat. Areas J. 33, 81-90.

De Lillo, E., Panzarino, O., Loverre, P., Valenzano, D., Mattia, C., Marini, F., Augé, M., Cristofaro, M., 2017. New eriophyoid mites from Italy. IV. Mites associated with weed plants. Syst. Appl. Acarol. 22, 2256-2273.

Derr, J.F., 2008. Common reed (Phragmites australis) response to mowing and herbicide application. Invas. Plant Sci. Manag. 1, 12-16.

DiTomaso, J.M., 2000. Invasive weeds in rangelands: species, impacts, and management. Weed Sci. 48, 255-265.

DiTomaso, J.M., Kyser, G.B., 2015. Effects of aminopyralid on California annual grassland plant communities. Invas. Plant Sci. Manag. 8, 98-109.

DiTomaso, J.M., Kyser, G.B., Miller, J.R., Garcia, S., Smith, R.F., Nader, G., Connor, J.M., Orloff, S.B., 2006. Integrating prescribed burning and clopyralid for the management of yellow starthistle (Centaurea solstitialis). Weed Sci. 54, 757-767.

DiTomaso, J.M., Kyser, G.B., 2007. Control of Ailanthus altissima using stem herbicide application techniques. Arboricult. Urban Forest. 33, 55-63.

Dodd, J.D., Holtz, S.T., 1972. Integration of burning with mechanical manipulation of south Texas grassland. J. Range Manag. 25, 130-136.

Dormaar, J., Johnston, A., Smoliak, S., 1979. Soil changes under crested wheatgrass. Canada Agric. 24, 757-767.

Dormaar, J.F., Naeth, M.A., Willms, W.D., Chanasyk, D.S., 1995. Effect of native prairie, crested wheatgrass (Agropyron cristatum (L.) Gaertn.) and Russian wildrye (Elymus junceus Fisch.) on soil chemical properties. J. Range Manag. 48, 258-263.
Dudley, T.L., Bean, D.W., 2012. Tamarisk biocontrol, endangered species risk and resolution of conflict through riparian restoration. BioControl 57, 331-347.

Dukes, J.S., Mooney, H.A., 1999. Does global change increase the success of biological invaders. Trends Ecol. Evolut. 14, 135-139.

Ehrenfeld, J.G., 2003. Effects of exotic plant invasions on soil nutrient cycling processes. Ecosystems 6, 503-523.

Ellis-Felege, S.N., Dixon, C.S., Wilson, S.D., 2013. Impacts and management of invasive cool-season grasses in the northern Great Plains: Challenges and opportunities for wildlife. Wildlife Soc. Bull. 37, 510-516.

Emam, T. 2016. Local soil, but not commercial AMF inoculum, increases native and non-native grass growth at a mine restoration site. Restor. Ecol. 24, 35-44.

Engle, D.M., 1985. Effects of eastern redcedar on range forage and livestock produc tion. In: Wittner, R.F., Engle, D.M. (Eds.), Proceedings of the Eastern Redcedar in Oklahoma Conference, Stillwater, OK. Oklahoma State University Cooperative Extension Service, pp. 53-60 20 February 1985E-849.

Engle, D.M., Coppedge, B.R., Fuhlendorf, S.D., 2008. From the dust bowl to the green glacier: human activity and environmental change in Great Plains grasslands. Western North American Juniperus Communities. Springer, pp. 253-271.

Enloe, S.F., DiTomaso, J.M., Orloff, S.B., Drake, D.J., 2005. Perennial grass establishment integrated with clopyralid treatment for yellow starthistle management on annual range. Weed Technol. 19, 94-101.

Erickson, A.M., Lym, R.G., Kirby, D., 2006. Effect of herbicides for leafy spurge control on the western prairie fringed orchid. Rangel. Ecol. Manag. 59, 462-467.

Espeland, E., Perkins, L., 2013. Annual cover crops do not inhibit early growth of perennial grasses on a disturbed restoration soil in the Northern Great Plains. Restor. Ecol. 31, 69-79.

Espeland, E., Richardson, L., 2015. The role of competition and seed production environment on the success of two perennial grass species in a roadside restoration. Ecol. Restor. 33, 282-288.

Espeland, E.K., Hendrickson, J., Toledo, D., West, N.M., Rand, T.A., 2017. Soils Determine early revegetation establishment with and without cover crops in northern mixed grass prairie after energy development. Ecol. Restor. 35, 311-319.

Fahey, D.W., Doherty, S.J., Hibbard, K.A., Romanou, A., Taylor, P.C., 2017. Physical drivers of climate change. In: Wuebbles, D.J., Fahey, D.W., Hibbard, K.A. Dokken, D.J., Stewart, B.C., Maycock, T.K. (Eds.), Climate Science Special Report: Fourth National Climate Assessment. U.S. Global Change Research Program, Washington, DC, USA, pp. 73-113 Volume I..

Frid, L., Hanna, D., Korb, N., Bauer, B., Bryan, K., Martin, B., Holzer, B., 2013. Evaluating alternative weed management strategies for three Montana landscapes. Invas. Plant Sci. Manag. 6, 48-59.

Folts-Zettner, T., H. Sosinski, R. Bennetts, K. Gallo, C. McIntyre, M. Powell, S. Studd, and K. Bonebrake. 2016. Multi-network exotic plant monitoring protocol: A collaboartion among the Southern Plains, Sonoran Desert, and Chihuahuan Desert Networks - Narrative version 1.00. Natural Resource Report NPS/SOPN/NRR2016/1304. National Park Service, Fort Collins, Colorado.

Frost, R.A., Launchbaugh, K.L., 2003. Prescription grazing for rangeland weed management - a new look at an old tool. Rangelands 25, 43-47.

Frost, J.S., Powell, L.A., 2011. Cedar infestation impacts avian communities along the Niobrara River Valley, Nebraska. Restor. Ecol. 19, 529-536.

Fuhlendorf, S.D., Archer, S.A., Smeins, F., Engle, D.M., Taylor, C.A., 2008. The combined influence of grazing, fire, and herbaceous productivity on treegrass interactions. Western North American Juniperus Communities. Springer pp. 219-238.

Gaffke, A.M., Sing, S.E., Dudley, T.L., Bean, D.W., Russak, J.A., Mafra-Neto, A. Grieco, P.A., Peterson, R.K., Weaver, D.K., 2018. Semiochemicals to enhance herbivory by Diorhabda carinulata aggregations in saltcedar (Tamarix spp.) infestations. Pest Manag. Sci. 74, 1494-1503.

Galatowitsch, S., Frelich, L., Phillips-Mao, L., 2009. Regional climate change adaptation strategies for biodiversity conservation in a midcontinental region of North America. Biol. Conserv. 142, 2012-2022.

Ganguli, A.C., Engle, D.M., Mayer, P.M., Fuhlendorf, S.D., 2008. When are native species inappropriate for conservation plantings. Rangelands 30, 27-32.

Gassmann, A., Louda, S.M., 2001. Rhinocyllus conicus: initial evaluation and subsequent ecological impacts in North America. Facul. Publ. Biol. Sci. 8, 147-183.

Gassmann, A., De Clerck-Floate, R., Sing, S., Toševski, I., Mitrović, M., Krstić, O., 2014 Biology and host specificity of Rhinusa pilosa, a recommended biological control agent of Linaria vulgaris. BioControl 59, 473-483.

Gehring, J.L., Bragg, T.B., 1992. Changes in prairie vegetation under eastern red cedar (Juniperus virginiana L.) in an eastern Nebraska bluestem prairie. Am. Midland Natural. 128, 209-217.

Gibbons, S.M., Lekberg, Y., Mummey, D.L., Sangwan, N., Ramsey, P.W., Gilbert, J.A., 2017. Invasive plants rapidly reshape soil properties in a grassland ecosystem. mSystems 2 e00178-e00116.

Goodwin, K., Sheley, R., Jacobs, J., Wood, S., Manoukian, M., Schuldt, M., Miller, E., Sackman, S., 2012. Cooperative prevention systems to protect rangelands from the spread of invasive plants. Rangelands 34, 26-31.

Grant, T.A., Flanders-Wanner, B., Shaffer, T.L., Murphy, R.K., Knutsen, G.A., 2009. An emerging crisis across Northern Prairie Refuges: Prevalence of invasive plants and a plan for adaptive management. Ecol. Restor. 27, 58-65.

Grant, T.A., Murphy, R.K., 2005. Changes in woodland cover on prairie refuges in North Dakota, USA. Nat. Areas J. 25, 359-368.

Grossmann, K., 1998. Quinclorac belongs to a new class of highly selective auxin herbicides. Weed Sci. 46, 707-716.

Grover, H.D., Musick, H.B., 1990. Shrubland encroachment in southern New Mexico, USA: an analysis of desertification processes in the American Southwest. Clim. Change 17, 305-330 
Haddad, N.M., Brudvig, L.A., Damschen, E.I., Evans, D.M., Johnson, B.L., Levey, D.J., Orrock, J.L., Resasco, J., Sullivan, L.L., Tewksbury, J.J., 2014. Potential negative ecological effects of corridors. Conserv. Biol. 28, 1178-1187.

Hajny, K.M., Hartnett, D.C., Wilson, G.W., 2011. Rhus glabra response to season and intensity of fire in tallgrass prairie. Int. J. Wildl. Fire 20, 709-720.

Hamman, S.T., Hawkes, C.V., 2013. Biogeochemical and microbial legacies of nonnative grasses can affect restoration success. Restor. Ecol. 21, 58-66.

Hatcher, P.E., Melander, B., 2003. Combining physical, cultural and biological methods: prospects for integrated non-chemical weed management strategies. Weed Res, 43, 303-322.

Havill, S., Schwinning, S., Lyons, K.G., 2015. Fire effects on invasive and native war$\mathrm{m}$-season grass species in a North American grassland at a time of extreme drought. Appl. Veg. Sci. 18, 637-649.

Hawkes, C.V., Belnap, J., D’Antonio, C., Firestone, M.K., 2006. Arbuscular mycorrhizal assemblages in native plant roots change in the presence of invasive exotic grasses. Plant Soil 281, 369-380.

Hein, D.G., Miller, S.D., 1991. Leafy spurge (Euphorbia esula) response to single and repetitive picloram treatments. Weed Technol. 5, 881-883.

Hendrickson, J.R., Lund, C., 2010. Plant community and target species affect responses to restoration strategies. Rangel. Ecol. Manag. 63, 435-442.

Hobbs, R.J., Humphries, S.E., 1995. An integrated approach to the ecology and management of plant invasions. Conserv. Biol. 9, 761-770.

Hodgkinson, K., Harrington, G., 1985. The case for prescribed burning to control shrubs in eastern semi-arid woodlands. Rangel. J. 7, 64-74.

Horncastle, V.J., Hellgren, E.C., Mayer, P.M., Ganguli, A.C., Engle, D.M., Leslie, D.M., 2005. Implications of invasion by Juniperus virginiana on small mammals in the southern Great Plains. J. Mammal. 86, 1144-1155.

Howe, H.F., Brown, J.S., Zorn-Arnold, B., 2002. A rodent plague on prairie diversity. Ecol. Lett. 5, 30-36

Hulme, P.E., 2006. Beyond control: wider implications for the management of biological invasions. J. Appl. Ecol. 43, 835-847.

Jacobs, J.S., Sheley, R.L., 2005. The effect of season of picloram and chlorsulfuron application on Dalmatian Toadflax (Linaria genistifolia) on prescribed burns. Weed Technol. 19, 319-324.

James, J.J., Svejcar, T.J., Rinella, M.J., 2011. Demographic processes limiting seedling recruitment in arid grassland restoration. J. Appl. Ecol. 48, 961-969.

Johnston, A., Peake, R.W., 1960. Effect of Selective Grazing by Sheep on the Control of Leafy Spurge (Euphorbia esula L.). Rangel. Ecol. Manag./J. Range Manag. Arch. 13, 192-195.

Johnson, N., 1998. Responses of Salsola kali and Panicum virgatum to mycorrhizal fungi, phosphorus and soil organic matter: Implications for reclamation. J. Appl. Ecol. 35, 86-94.

Jones, T.A., Monaco, T.A., 2007. A restoration practitioner's guide to the restoration gene pool concept. Ecol. Restor. 25, 12-19.

Jordan, N.R., Larson, D.L., Huerd, S.C., 2008. Soil modification by invasive plants: Effects on native and invasive species of mixed-grass prairies. Biol. Invas. 10, 177-190.

Joyce, L.A., D. Ojima, G.A. Seielstad, R. Harriss, and J. Lackett. 2001. Potential consequences of climate variability and change for the Great Plains. Climate Change Impacts on the United States-Foundation Report: The Potential Consequences of Climate Variability and Change. pp. 191-217.

Kennedy, A.C., 2018. Selective soil bacteria to manage downy brome, jointed goatgrass, and medusahead and do no harm to other biota. Biol. Control 123, 18-27.

Kettenring, K.M., Mercer, K.L., Adams, C.R., Hines, J., 2014. Application of genetic diversity- ecosystem function research to ecological restoration. J. Appl. Ecol. 51, 339-348.

Kimoto, C., DeBano, S.J., Thorp, R.W., Taylor, R.V., Schmalz, H., DelCurto, T., Johnson, T., Kennedy, P.L., Rao, S., 2012. Short-term responses of native bees to livestock and implications for managing ecosystem services in grasslands. Ecosphere 3, 1-19.

Knight, K.S., Kurylo, J.S., Endress, A.G., Stewart, J.R., Reich, P.B., 2007. Ecology and ecosystem impacts of common buckthorn (Rhamnus cathartica): a review. Biol. Invas. 9, 925-937.

Knutson, T., Kossin, J.P., Mears, C., Perlwitz, J., Wehner, M.F., 2017. Detection and attribution of climate change. In: Wuebbles, D., Fahey, D.W., Hibbard, K.A., Dokken, D.J., Stewart, A.J., Maycock, T.K. (Eds.), Climate Science Special Report: Fourth National Climate Assessment, Volume I. U.S. Global Change Research Program, Washington, DC, USA, pp. 114-132.

Kobiela, B., Quast, J., Dixon, C., DeKeyser, E.S., 2017. Targeting introduced species to improve plant community composition on USFWS-Managed Prairie Remnants. Nat. Areas J. 37, 150-160.

Köchy, M., Wilson, S.D., 2001. Nitrogen deposition and forest expansion in the northern Great Plains. J. Ecol. 89, 807-817.

Koziol, L., Bever, J.D., 2017. The missing link in grassland restoration: arbuscular mycorrhizal fungi inoculation increases plant diversity and accelerates succession. J. Appl. Ecol. 54, 1301-1309.

Kramp, B., Ansley, R., Tunnell, T., 1998. Survival of mesquite seedlings emerging from cattle and wildlife feces in a semi-arid grassland. Southwest. Natural. 43, 300-312.

Krueger-Mangold, J., Sheley, R.L., Roos, B.D., 2002. Maintaining plant community diversity in a waterfowl production area by controlling Canada thistle (Cirsium arvense) using glyphosate. Weed Technol. 16, 457-463.

Kulmatiski, A., 2011. Changing soils to manage plant communities: activated carbon as a restoration tool in ex-arable fields. Restor. Ecol. 19, 102110 .
Kulmatiski, A., Beard, K.H., 2006. Activated carbon as a restoration tool: Potential for control of invasive plants in abandoned agricultural fields. Restor. Ecol. 14, 251-257.

Kulmatiski, A., Beard, K.H., Stevens, J.R., Cobbold, S.M., 2008. Plant-soil feedbacks: A meta-analytical review. Ecol. Lett. 11, 980-992.

Lake, E.C., Minteer, C.R., 2018. A review of the integration of classical biological control with other techniques to manage invasive weeds in natural areas and rangelands. BioControl 63, 1-16.

Larson, D.L., Larson, J.L., 2010. Control of one invasive plant species allows exotic grasses to become dominant in northern Great Plains grasslands. Biol. Conserv. 143, 1901-1910.

Larson, D.L., Ahlering, M.A., Drobney, P., Esser, R., Larson, J.L., Viste-Sparkman, K. 2018. Developing a framework for evaluating tallgrass prairie reconstruction methods and management. Ecol. Restor. 36, 6-18.

Launchbaugh, K., Walker, J., 2006. Targeted grazing-a new paradigm for livestock management. Targeted Grazing: A Natural Approach to Vegetation Management and Landscape Enhancement. American Sheep Industry Association, Centennial, CO, USA, pp. 2-8 Section 1.

Leffler, A.J., Sheley, R.L., 2012. Adaptive management in EBIPM: a key success in invasive plant management. Rangelands 34, 44-47.

Lesica, P., DeLuca, T.H., 1996. Long-term harmful effects of crested wheatgrass on Great Plains grassland ecosystems. J. Soil Water Conserv. 51, 408-409.

Lett, M.S., Knapp, A.K., Briggs, J.M., Blair, J.M., 2004. Influence of shrub encroachment on aboveground net primary productivity and carbon and nitrogen pools in a mesic grassland. Canadian J. Botany 82, 1363-1370.

Leung, B., Lodge, D.M., Finnoff, D., Shogren, J.F., Lewis, M.A., Lamberti, G., 2002. An ounce of prevention or a pound of cure: bioeconomic risk analysis of invasive species. Proc. R. Soc. Lond. B: Biol. Sci. 269, 2407-2413.

Limb, R.F., Engle, D.M., Alford, A.L., Hellgren, E.C., 2010. Tallgrass prairie plant community dynamics along a canopy cover gradient of eastern redcedar (Juniperus virginiana L.). Rangel. Ecol. Manag. 63, 638-644.

Limb, R.F., Engle, D.M., Alford, A.L., Hellgren, E.C., 2014. Plant community response following removal of Juniperus virginiana from tallgrass prairie: Testing for restoration limitations. Rangel. Ecol. Manag. 67, 397-405.

Liu, S., Walshe, T., Long, G., Cook, D., 2012. Evaluation of potential responses to invasive non-native species with structured decision making. Conserv. Biol. 26, 539-546.

Louda, S.M., O'Brien, C.W., 2002. Unexpected ecological effects of distributing the exotic weevil, Larinus planus (F.), for the biological control of Canada thistle. Conserv. Biol. 16, 717-727.

Lym, R.G., 1998. The biology and integrated management of leafy spurge (Euphorbia esula) on North Dakota rangeland. Weed Technol. 12, 367-373.

Lym, R.G., Messersmith, C.G., 1985. Leafy spurge control with herbicides in North Dakota: 20-year summary. J. Range Manag. 38, 149-154.

Lym, R.G., Nelson, J.A., 2002. Integration of Aphthona spp. flea beetles and herbicides for leafy spurge (Euphorbia esula) control. Weed Sci. 50, 812-819.

Lym, R.G., Sedivec, K.K., Kirby, D.R., 1997. Leafy spurge control with angora goats and herbicides. J. Range Manag. 50, 123-128.

Madsen, M.D., Davies, K.W., Boyd, C.S., Kerby, J.D., Svejcar, T.J., 2016. Emerging seed enhancement technologies for overcoming barriers to restoration. Restor. Ecol. 24, S77-S84.

Mangin, A.R., Hall, L.M., 2016. First report: spotted knapweed (Centaurea stoebe) resistance to auxinic herbicides. Canad. J. Plant Sci. 96, 928-931.

Maguire, L.A., 2004. What can decision analysis do for invasive species management. Risk Anal. 24, 859-868.

Masters, R.A., Sheley, R.L., 2001. Principles and practices for managing rangeland invasive plants. J. Range Manag. 54, 502-517.

Mattise, S.N., Scholten, G., 1994. Mechanical control of undesirable annuals on the Boise Front, Idaho. In: Monsen, S.B., Kitchen, S.G. (Eds.), Proceedings of the Ecology and Management of Annual Rangelands. Ogden, UT: US Department of Agriculture, Forest Service. Intermountain Research Station General Technical Report INT-GTR-313, pp. 190-193.

McFadyen, R.C., 2000. Successes in biological control of weeds. In: Proceedings of the X international symposium on biological control of weeds, Great Falls, MT. Advanced Litho Printing, pp. 3-14.

Middleton, E.L., Bever, J.D., 2012. Inoculation with a Native Soil Community Advances Succession in a Grassland Restoration. Restor. Ecol. 20, 218-226.

Miller, R.F., Rose, J.A., 1999. Fire history and western juniper encroachment in sagebrush steppe. J. Range Manag. 52, 550-559.

Miller, R.F., Svejcar, T.J., Rose, J.A., 2000. Impacts of western juniper on plant community composition and structure. J. Range Manag. 53, 574-585.

Miller, T.W., 2016. Integrated strategies for management of perennial weeds. Invas. Plant Sci. Manag. 9, 148-158.

Montana Administrative Register. 2019. http://sos.mt.gov/ARM/Register [accessed November 2019]

Montana Invasive Species Council. 2019. Key Findings of Mogulones crucifer Science Advisory Panel: http://dnrc.mt.gov/divisions/cardd/docs/misac-docs/ mcrucifersap_keyfindings_final.pdf [accessed November 2019]

Moore, C.T., Shaffer, T.L., Gannon, J.J., 2013. Spatial education: improving conservation delivery through space-structured decision making. J. Fish and Wildlife Management 4, 199-210.

Moore, C.T., Gannon, J.J., Shaffer, T.L., Dixon, C.S., 2020. An adaptive approach to vegetation management in native prairies of the northern Great Plains. Chapter 23. In: Runge, M.C., Converse, S.J., Lyons, J.E., Smith, D.R. (Eds.), Structured Decision Making: Case Studies in Decision Analysis for Natural Resources Management editors. Johns Hopkins University Press, Washington, D.C. 
Mummey, D.L., Rillig, M.C., 2006. The invasive plant species Centaurea maculosa alters arbuscular mycorrhizal fungal communities in the field. Plant Soil 288, 81-90.

Nielsen, A.M., Fei, S., 2015. Assessing the flexibility of the Analytic Hierarchy Process for prioritization of invasive plant management. NeoBiota 27, 25-36.

Olson, E. 1997. National Grasslands Management: A Primer. Natural Resources Division, Office of the General Counsel, U.S. Department of Agriculture. http:// www.fs.fed.us/grasslands/resources/documents/primer/NG_Primer.pdf [accessed November 2019]

Olsen, H.E., G. Block, and C.V. Ransom. 2015. An Invasive Plant Inventory and Early Detection Prioritization Tool. https://catalog.data.gov/dataset/ an-invasive-plant-inventory-and-early-detection-prioritization-tool-version-2-0 [accessed November 2019]

Ortega, Y.K., Pearson, D.E., 2010. Effects of picloram application on community dominants vary with initial levels of spotted knapweed (Centaurea stoebe) invasion. Invas. Plant Sci. Manag. 3, 70-80.

Park, I., Eigenbrode, S.D., Cook, S.P., Harmon, B.L., Hinz, H.L., Schaffner, U., Schwarzländer, M., 2018. Examining olfactory and visual cues governing host-specificity of a weed biological control candidate species to refine pre-release risk assessment. BioControl 63, 377-389.

Pauly, D., 1995. Anecdotes and the shifting baseline syndrome of fisheries. Trends Ecol. Evolut. 10, 430.

Pearson, D.E., Ortega, Y.K., Runyon, J.B., Butler, J.L., 2016a. Secondary invasion: the bane of weed management. Biol. Conserv. 197, 8-17.

Pearson, D.E., Ortega, Y.K., Eren, Ö., Hierro, J.L., 2016b. Quantifying “apparent” impact and distinguishing impact from invasiveness in multispecies plant invasions. Ecol. Appl. 26, 162-173.

Pearson, D.E., and Y.K. Ortega. 2017. Exotic plant impacts in western wheatgrass communities of east-central Montana, Preliminary Report to Montana Noxious Weed Trust Fund p. 9.

Pearson, D.E., Ortega, Y.K., Maron, J.L., 2017. The tortoise and the hare: reducing resource availability shifts competitive balance between plant species. J. Ecol. 105, 999-1009.

Pearson, D.E., Valliant, M., Carlson, C., Thelen, G.C., Ortega, Y.K., Orrock, J.L., Madsen, M.D., 2019. Spicing up restoration: can chili peppers improve restoration seeding by reducing seed predation. Restor. Ecol. 27, 254-260.

Perkins, L.B., Bennett, J.R., 2018. A field test of commercial soil microbial treatments on native grassland restoration. Restor. Ecol. 26, 851-857.

Perkins, L.B., Hatfield, G., Espeland, E.K., 2016. Invasive grasses consistently create similar plant-soil feedback types in soils collected from geographically distant locations. J. Plant Ecol. 9, 180-186.

Perry, G.L., Moloney, K.A., Etherington, T.R., 2017. Using network connectivity to prioritise sites for the control of invasive species. J. Appl. Ecol. 54, 1238-1250.

Pokorny, M.L., Mangold, J.M., Hafer, J., Denny, M.K., 2010. Managing spotted knapweed (Centaurea stoebe)-infested rangeland after wildfire. Invas. Plant Sci. Manag. 3, 182-189.

Popay, I., Field, R., 1996. Grazing animals as weed control agents. Weed Technol. 10, 217-231.

Porensky, L.M., Blumenthal, D.M., 2016. Historical wildfires do not promote cheatgrass invasion in a western Great Plains steppe. Biol. Invas. 18, 3333-3349.

Porensky, L.M., Young, T.P., 2013. Edge-effect interactions in fragmented and patchy landscapes. Conserv. Biol. 27, 509-519.

Post van der Burg, M., A.J. Symstad, L.D. Igl, D.M. Mushet, D.L. Larson, G.A. Sargeant, D.D. Harper, A.M. Farag, B.A. Tangen, and M.J. Anteau. 2017. Potential Effects of Energy Development on Environmental Resources of the Williston Basin in Montana, North Dakota, and South Dakota-Species of Conservation Concern. U.S. Geological Survey Scientific Investigations Report 2017-5070-D.

Price, J.R. 2014. Post-release Assessment of Classical Biological Control of Canada Thistle (Cirsium arvense) in the Western United States: Dissertation submitted to University of Idaho. https://digital.lib.uidaho.edu/digital/collection/etd/id/571/ [accessed November 2019]

Pringle, R.M., Goheen, J.R., Palmer, T.M., Charles, G.K., DeFranco, E., Hohbein, R., Ford, A.T., Tarnita, C.E., 2014. Low functional redundancy among mammalian browsers in regulating an encroaching shrub (Solanum campylacanthum) in African savannah. Proc. R. Soc. B: Biol. Sci. 281, 20140390.

Ralphs, M.H., Turner, D.L., Mickelsen, L.V., Evans, J.O., Dewey, S.A., 1990. Herbicides for control of tall larkspur (Delphinium barbeyi). Weed Sci. 38, 573-577.

Ratajczak, Z., Nippert, J.B., Briggs, J.M., Blair, J.M., 2014. Fire dynamics distinguish grasslands, shrublands and woodlands as alternative attractors in the Central Great Plains of North America. J. Ecology 102, 1374-1385.

Ratajczak, Z., Nippert, J.B., Collins, S.L., 2012. Woody encroachment decreases diversity across North American grasslands and savannas. Ecology 93, 697-703.

Reeves, J.L., Blumenthal, D.M., Kray, J.A., Derner, J.D., 2015. Increased seed consumption by biological control weevil tempers positive CO 2 effect on invasive plant (Centaurea diffusa) fitness. Biol. Control 84, 36-43.

Renz, M.J., DiTomaso, J.M., 2006. Early season mowing improves the effectiveness of chlorsulfuron and glyphosate for control of perennial pepperweed (Lepidium latifolium). Weed Technol. 20, 32-36.

Rice, P.M., Toney, J.C., 1998. Exotic weed control treatments for conservation of fescue grassland in Montana. Biol. Conserv. 85, 83-95.

Rice, P.M., Toney, J.C., Bedunah, D.J., Carlson, C.E., 1997. Plant community diversity and growth form responses to herbicide applications for control of Centaurea maculosa. J. Appl. Ecol. 1397-1412.

Richardson, L.A., Juricek, C.J., Lym, R.G., Kirby, D.R., Tober, D.A., 2008. Integrated leafy spurge (Euphorbia esula) control using imazapic, Aphthona spp. biologi- cal control agents, and seeded native grasses. Invas. Plant Sci. Manag. 1, 255264.

Robertson, S., Hickman, K.R., Harmoney, K.R., Leslie Jr., D.M., 2013. Combining glyphosate with burning or mowing improves control of yellow bluestem (Bothriochloa ischaemum). Rangel. Ecol. Manag. 66, 376-381.

Rogler, G.A., Lorenz, R.J., 1983. Crested wheatgrass: early history in the United States. J. Range Manag. 36, 91-93.

Rosenstock, S.S., Van Riper, C. III., 2001. Breeding bird responses to juniper woodland expansion. J. Range Manag. 54, 226-232.

Rowe, C.L., Leger, E.A., 2012. Seed source affects establishment of Elymus multisetus in postfire revegetation in the Great Basin. Western North Am. Natur. 72, 543-553.

Rowe, H.I., Brown, C.S., Claassen, V.P., 2007. Comparisons of mycorrhizal responsiveness with field soil and commercial inoculum for six native montane species and Bromus tectorum. Restor. Ecol. 15, 44-52.

Rowe, H.I., Brown, C.S., Paschke, M.W., 2009. The influence of soil inoculum and nitrogen availability on restoration of high-elevation steppe communities invaded by Bromus tectorum. Restor. Ecol. 17, 686-694.

Runyon, J.B., Birdsall, J.L., 2016. Costs of induced defenses for the invasive plant houndstongue (Cynoglossum officinale L.) and the potential importance for weed biocontrol. Arthropod-Plant Interact. 10, 383-391.

Scholes, R., Archer, S., 1997. Tree-grass interactions in savannas. Annu. Rev. Ecol. Syst. 28, 517-544.

Scholtz, R., Polo, J.A., Fuhlendorf, S.D., Engle, D.M., Weir, J.R., 2018. Woody Plant Encroachment Mitigated Differentially by Fire and Herbicide. Rangel. Ecol. Manag. 71, 239-244.

Seastedt, T.R., Gregory, N., Buckner, D., 2003. Effect of biocontrol insects on diffuse knapweed (Centaurea diffusa) in a Colorado grassland. Weed Sci. 51, 237-245.

Sebastian, D.J., Fleming, M.B., Patterson, E.L., Sebastian, J.R., Nissen, S.J., 2017. Indaziflam: a new cellulose-biosynthesis-inhibiting herbicide provides long-term control of invasive winter annual grasses. Pest Manag. Sci. 73, 2149-2162.

Sebastian, D.J., Sebastian, J.R., Nissen, S.J., Beck, K.G., 2016. A potential new herbicide for invasive annual grass control on rangeland. Rangel. Ecol. Manag. 69, 195-198.

Shafer, M., Ojima, D., Antle, J., Kluck, D., McPherson, R., Petersen, S., Scanlon, B., Sherman, K., 2014. Ch. 19: Great Plains. In: Melillo, J.M., Richmond, T., Yohe, G.W. (Eds.), Climate Change Impacts in the United States: The Third National Climate Assessment. U.S. Global Change Research Program, pp. 441-461.

Sheley, R.L., Jacobs, J.S., 1997. Response of spotted knapweed and grass to picloram and fertilizer combinations. J. Range Manag. 50, 263-267.

Sheley, R.L., Jacobs, J.S., Martin, J.M., 2004. Integrating 2, 4-D and sheep grazing to rehabilitate spotted knapweed infestations. J. Range Manag. 57, 371-375.

Sheley, R., James, J., Smith, B., Vasquez, E., 2010. Applying ecologically based invasive-plant management. Rangel. Ecol. Manag. 63, 605-613.

Sheppard, A., Van Klinken, R., Heard, T., 2005. Scientific advances in the analysis of direct risks of weed biological control agents to nontarget plants. Biol. Control $35,215-226$.

Siemann, E., Rogers, W.E., Grace, J.B., 2007. Effects of nutrient loading and extreme rainfall events on coastal tallgrass prairies: invasion intensity, vegetation responses, and carbon and nitrogen distribution. Glob. Change Biol. 13, 2184-2192.

Simmers, S.M., Galatowitsch, S.M., 2010. Factors Affecting Revegetation of Oil Field Access Roads in Semiarid Grassland. Restor. Ecol. 18, 27-39.

Simmons, M.T., Windhager, S., Power, P., Lott, J., Lyons, R.K., Schwope, C., 2007. Selective and non-selective control of invasive plants: the short-term effects of growing-season prescribed fire, herbicide, and mowing in two Texas prairies. Restor. Ecol. 15, 662-669.

Sing, S.E., De Clerck-Floate, R., Hansen, R.W., Pearce, H., Randall, C.B., Tosevski, I. Ward, S.M., 2016. Biology and biological control of Dalmatian and yellow toadflax. FHTET-2016-01. Morgantown. WV: US Department of Agriculture, 141. Forest Service, Forest Health Technology Enterprise Team.

Stankey, G.H., Clark, R.N., Bormann, B.T., 2005. Adaptive management of natural resources: theory, concepts, and management institutions. Gen. Tech. Rep. PNW-GTR-654. Portland, OR: US Department of Agriculture, Forest Service. Pac Northwest Res. Station 73, 654.

Sutton, P. 2000. What are stretch goals. www.green-innovations.asn.au/ stretch-goals/Stretch-goals-resources.htm [accessed November 2019].

Sutton, G.F., Canavan, K., Day, M.D., den Breeyen, A., Goolsby, J.A., Cristofaro, M., McConnachie, A., Paterson, I.D., 2019. Grasses as suitable targets for classical weed biological control. BioControl 64, 605-622.

Sylvain, Z.A., Branson, D.H., Rand, T.A., West, N.M., Espeland, E.K., 2019. Decoupled recovery of communities after reclamation. Peer] 7, e7038.

Symstad, A.J., R.A. Gitzen, C.L. Wienk, M.R. Bynum, D.J. Swanson, A.D. Thorstenson, and K.J. Paintner. 2012. Plant community composition and structure monitoring protocol for the Northern Great Plains I\&M Network: version 1.01. Natural Resource Report NPS/NGPN/NRR-2012/489. National Park Service, Fort Collins, Colorado.

Symstad, A.J., Leis, S.A., 2017. Woody encroachment in northern Great Plains grasslands: perceptions, actions, and needs. Nat. Areas J. 37, 118-127.

Symstad, A.J., Smith, A.T., Newton, W.E., Knapp, A.K., 2019. Experimentally derived nitrogen critical loads for northern Great Plains vegetation. Ecol. Appl. 29, e01915.

Thiele, J., Kollmann, J., Markussen, B., Otte, A., 2010. Impact assessment revisited: improving the theoretical basis for management of invasive alien species. Biol. Invas. 12, 2025-2035. 
Toševski, I., Jović, J., Krstić, O., Gassmann, A., 2013. PCR-RFLP-based method for reliable discrimination of cryptic species within Mecinus janthinus species complex (Mecinini, Curculionidae) introduced in North America for biological control of invasive toadflaxes. BioControl 58, 563-573.

Twidwell, D., Fuhlendorf, S.D., Taylor, C.A., Rogers, W.E., 2013. Refining thresholds in coupled fire-vegetation models to improve management of encroaching woody plants in grasslands. J. Appl. Ecol. 50, 603-613.

Ueckert, D.N., Phillips, R.A., Petersen, J.L., Ben Wu, X., Waldron, D.F., 2001. Redberry juniper canopy cover dynamics on western Texas rangelands. J. Range Manag. 54, 603-610.

USDA, 2001. Guide to Noxious Weed Prevention Practices. USDA-Forest Service.

USDA Forest Service, 2015. The Rising Cost of Wildfire Operation. Effects on the Forest Service's Non-Fire Work, p. 16.

USGCRP, 2017. Climate Science Special Report: Fourth National Climate Assessment. U.S. Global Change Research Program, Volume 1, p. 470.

Van Auken, O.W., 2000. Shrub invasions of North American semiarid grasslands. Annu. Rev. Ecol. Syst. 31, 197-215.

Van de Water, P.K., Keever, T., Main, C.E., Levetin, E., 2003. An assessment of predictive forecasting of Juniperus ashei pollen movement in the Southern Great Plains, USA. Int. J. Biometeorol. 48, 74-82.

van Der Putten, W.H., Klironomos, J.N., Wardle, D.A., 2007. Microbial ecology of biological invasions. ISME Journal 1, 28-37.

Vaness, B.M., Wilson, S.D., 2007. Impact and management of crested wheatgrass (Agropyron cristatum) in the northern Great Plains. Canad. J. Plant Sci. 87, 1023-1028.

Vermeire, L.T., Crowder, J.L., Wester, D.B., 2011. Plant community and soil environment response to summer fire in the northern Great Plains. Rangel. Ecol. Manag. 64, 37-46.

Viall, E.M., Gentry, L.F., Hopkins, D.G., Ganguli, A.C., Stahl, P., 2014. Legacy effects of oil road reclamation on soil biology and plant community composition. Restor. Ecol. 22, 625-632.

Vink, S.N., Jordan, N.R., Huerd, S.C., Shaeffer, C.C., Kinkel, L.L., Aldrich-Wolfe, L., 2015. Soil conditioning effects of native and exotic grassland perennials on the establishment of native and exotic plants. Plant Soil 393, 335-349.

Vitelli, J.S., 2000. Options for effective weed management. Trop Grassl 34, 280-294.

Vitelli, J.S., Pitt, J.L., 2006. Assessment of current weed control methods relevant to the management of the biodiversity of Australian rangelands. Rangel. J. 28, $37-46$.

Vivanco, J.M., Bais, H.P., Stermitz, F.R., Thelen, G.C., Callaway, R.M., 2004. Biogeographical variation in community response to root allelochemistry: Novel weapons and exotic invasion. Ecol. Lett. 7, 285-292.

Ward, S.M., Fleischmann, C.E., Turner, M.F., Sing, S.E., 2009. Hybridization between invasive populations of Dalmatian toadflax (Linaria dalmatica) and yellow toadflax (Linaria vulgaris). Invas. Plant Sci. Manag. 2, 369-378.

Watson, R.T., M.C. Zinyowera, R.H. Moss, and D.J. Dokken. 1998. The regional impacts of climate change. An assessment of vulnerability: A Special Report of IPCC Working Group II:517.
Wessman, C.A., S.R. Archer, G.P. Asner, and C. Bateson. 2004. Quantifying Grasslandto-Woodland Transitions and the Implications for Carbon and Nitrogen Dynamics in the Southwest United States. Final Report for NASA Grant NAG5-6134

West, A.J., 1988. Conservation reserve tree planting: Can we improve upon success. J. Soil Water Conserv. 43, 66-67.

Wheeler, G.S., Schaffner, U., 2013. Improved understanding of weed biological control safety and impact with chemical ecology: a review. Invas. Plant Sci. Manag. 6, 16-29.

Wilkerson, M.L., 2013. Invasive plants in conservation linkages: a conceptual model that addresses an underappreciated conservation issue. Ecography 36, 1319-1330.

Willson, G.D., Stubbendieck, J., 1997. Fire effects on four growth stages of smooth brome (Bromus inermis Leyss.). Nat. Areas J. 17, 306-312.

Wilson, G.W.T., Hickman, K.R., Williamson, M.M., 2012. Invasive warm-season grasses reduce mycorrhizal root colonization and biomass production of native prairie grasses. Mycorrhiza 22, 327-336.

Winston, R., Randall, C.B., Blossey, B., Tipping, P.W., Lake, E.C., Hough-Goldstein, J. 2017. Field Guide for the Biological Control of Weeds in the Northwest. USDA Forest Service, Forest Health Technology Enterprise Team, Morgantown, West Virginia.

Wisz, M.S., Pottier, J., Kissling, W.D., Pellissier, L., Lenoir, J., Damgaard, C.F., Dormann, C.F., Forchhammer, M.C., Grytnes, J.A., Guisan, A., 2013. The role of biotic interactions in shaping distributions and realised assemblages of species: implications for species distribution modelling. Biol. Rev, 88, 15-30.

Woodyard, A.J., Bollero, G.A., Riechers, D.E., 2009. Broadleaf weed management in corn utilizing synergistic postemergence herbicide combinations. Weed Technol. 23, 513-518.

WSSA, 2014. Herbicide Handbook. Weed Sci. Society of Amercia, Lawrence, KS, p. 513 .

Wubs, E.R.J., van der Putten, W.H., Bosch, M., Bezemer, T.M., 2016. Soil inoculation steers restoration of terrestrial ecosystems. Nat. Plants 2, 16107.

Young, C.C., Haack, J.L., Morrison, L.W., DeBacker, M.D., 2007. Invasive Exotic Plant Monitoring Protocol for the Heartland Network Inventory and Monitoring Program. Natural Resource Report NPS/MWR/HTLN/NRR-2007/018. National Park Service, Fort Collins, Colorado.

Zimmerman, C., Jordan, M., Sargis, G., Smith, H., Schwager, K., 2011. An invasive plant management decision analysis tool. Nat. Conserv.. http:/ greatlakesresilience.org/sites/default/files/library_reference_2011_TheNature Conservancy_IPMDAT.pdf. [accessed March 2019].

Ziska, L.H., 2003. Evaluation of the growth response of six invasive species to past present and future atmospheric carbon dioxide. J. Exp. Botany 54, 395-404

Zou, C.B., Turton, D.J., Will, R.E., Engle, D.M., Fuhlendorf, S.D., 2014. Alteration of hydrological processes and streamflow with juniper (Juniperus virginiana) encroachment in a mesic grassland catchment. Hydrol. Process. 28, 6173-6182. 